University of Louisville

ThinkIR: The University of Louisville's Institutional Repository

\title{
Obergefell v. Hodges and support for same-sex marriage : changes in national and state public opinion.
}

Adria Neal

Follow this and additional works at: https://ir.library.louisville.edu/honors

Part of the Law and Gender Commons, Lesbian, Gay, Bisexual, and Transgender Studies Commons, and the Sexuality and the Law Commons

\section{Recommended Citation}

Neal, Adria, "Obergefell v. Hodges and support for same-sex marriage : changes in national and state public opinion." (2016). College of Arts \& Sciences Senior Honors Theses. Paper 101.

http://doi.org/10.18297/honors/101

This Senior Honors Thesis is brought to you for free and open access by the College of Arts \& Sciences at ThinkIR: The University of Louisville's Institutional Repository. It has been accepted for inclusion in College of Arts \& Sciences Senior Honors Theses by an authorized administrator of ThinkIR: The University of Louisville's Institutional Repository. This title appears here courtesy of the author, who has retained all other copyrights. For more information, please contact thinkir@louisville.edu. 
Obergefell v. Hodges and Support for Same-Sex Marriage:

Changes in National and State Public Opinion

By

\section{Adria Neal}

Submitted in partial fulfillment of the requirements

for Graduation summa cum laude

and

For Graduation with Honors from the Department of Political Science

University of Louisville

May 2016 


\begin{abstract}
Many have argued that Supreme Court decisions on culture war issues, issues that cause conflict between conservative and liberal values, stifle public progression on the very problems they are meant to resolve. They often cite political and electoral backlash following a decision as evidence of this stagnation in opinion. However, this backlash may not be representative of widespread public opinion. In order to understand the relationship between Court decisions and public opinion, changes in opinion on culture war issues following a Supreme Court ruling must be measured. This study utilizes national and state survey data in order to examine this relationship. It measures changes in support for same-sex marriage nationwide as well as in the state of Kentucky following the Supreme Court's landmark decision in Obergefell v. Hodges, which legalized same-sex marriage nationwide. Changes in support for same-sex marriage among various racial groups, religious groups, and members of political parties following Obergefell are also assessed. Findings show that Court decisions precede changes in overall support as well as changes in the gaps in support between racial groups, religious groups, and parties. Changes in nationwide support following Obergefell did not reach significance; therefore, the effect of the decision on support could not be measured. Changes in support on the state level following the ruling also could not be determined because of differences in question wording following the decision. Future research should utilize survey data with consistent questions before and after the Court's ruling in order to adequately examine changes in support for same-sex marriage. It should also control for other variables in order to isolate the effect of Court decisions.
\end{abstract}




\section{Introduction}

The Hawaii Supreme Court's 1993 decision in Baehrv. Lewin spurred political and electoral backlash against same-sex marriage. Although the decision was not binding, the Court's rationale supported the constitutionality of same-sex marriage, thus providing legitimate arguments for the LGBT community and a means to continue pushing for the extension of marriage rights for same-sex couples. Following the decision, numerous states, including Hawaii, passed constitutional amendments proscribing same-sex marriage. Congress then passed the Defense of Marriage Act, which defined marriage as being between one man and one woman for federal purposes and allowed states to deny recognition to same-sex marriages performed in other states. Although these initiatives were either a result of public referenda or were enacted by duly elected bodies, it cannot be concluded that they reflected widespread public opinion on this issue. In fact, many argue that they did not mirror public preferences, but instead were a result of political countermobilization. Therefore, in order to adequately examine the relationship between public opinion and Court decisions, it is important to decipher between actual changes in public opinion following a decision and political backlash resulting from organized opposition.

This study investigates whether Court decisions on culture war issues affect public opinion regarding these issues. Specifically, it examines the effect of Obergefell v. Hodges, which legalized same-sex marriage nationwide, on support for same-sex marriage. It seeks to measure whether this landmark decision affirmed existing opinion on the issue, whether the ruling pushed opinion forward, or whether backlash to Court involvement rolled back support for same-sex marriage. Changes among racial groups, religious groups, and parties are also included in this study in order to determine whether support from any of these groups is disproportionately affected by Court involvement. Changes in support for same-sex marriage in 
the state of Kentucky are also measured. Because two of the consolidated cases in Obergefell $v$. Hodges came from Kentucky, studying changes in overall support in the state as well as changes among racial groups and parties further explains whether these decisions have a greater effect on the opinion of the individuals that are directly affected by them. National and state opinion polls taken before and after the landmark cases of U.S. v. Windsor and Hollingsworth v. Perry as well as other lower court rulings are utilized to determine if backlash to these cases is driving opinion on same-sex marriage. Changes following other significant events are also noted in order to account for the influence of other variables on changes in support for same-sex marriage. Previous research has investigated the effect of Court decisions on the advancement of social movements as well as the determinants of public support for LGBT rights. However, studying the effect of the Obergefell decision on national and state level opinion and measuring group behavior provides a nuanced perspective of the impact of Court involvement.

\section{Public Opinion on Same-Sex Marriage}

\section{Court Involvement in the Culture War}

Primarily, most researchers that have studied whether the Supreme Court can initiate social reform conclude that its attempts are ineffective because they incite political backlash and do not alter public opinion. Rosenberg (1991) asserts that the Court can enforce previous decisions made by other branches and can make decisions consistent with those of the legislative and executive branches, but it cannot make lasting social change on its own. Researchers have concluded that, because the Court does not have the power to implement its decisions, these decisions lead to the passage of policies that undermine the spirit of the ruling (Rosenberg 1991; Blake 1977; Lewis and Seong Soo Oh 2008). Rosenberg (1991) argues that litigation is an ineffective strategy for social movements for this very reason. Although they may experience 
initial success, this is limited by backlash following the decision. For example, following Roe $v$. Wade, anti-abortion proponents were elected, the Hyde Amendment was passed, and other antiabortion legislation was introduced. ${ }^{1}$ In regards to changes in public opinion, Rosenberg (1991) and Blake (1977) found no evidence that Court decisions have influenced public opinion, neither do they increase the salience of an issue. In fact, most citizens are not aware of Court decisions; therefore, any changes in opinion are not a result of a Supreme Court ruling (Rosenberg 1991; Blake 1977). These scholars find that Court intervention is counterproductive because it mobilizes the opposition, leading to attempts to overturn the decision, and does not change the public's perception of an issue.

Others have espoused similar views, concluding that most Court decisions do not affect opinion; however, when minute changes occur, they are often the result of other factors. Bishin (2015) found no change in opinion on same-sex marriage following the landmark decisions in Perry v. Schwarzenegger and U.S. v. Windsor. Bishin (2015) states that groups that are against same-sex marriage will continue to oppose it, while groups that support it will continue to do so, despite the opinion of judges. Some studies have found shifts in public opinion following Court decisions; however, scholars attribute these changes to other variables. Stoutenborough (2006) found that landmark decisions may cause shifts in public opinion, but other factors such as caseby-case elements, media coverage and framing of a decision, as well as the political context of a decision influence public awareness and perception about a ruling. For example, in Lawrence v. Texas, the Court legalized homosexual sodomy, but public support for same-sex relations declined. Stoutenborough (2006) attributes that decline to the media's negative depiction of the

\footnotetext{
1 The Hyde Amendment is a legislative provision that prohibits federal funding of abortions except in cases of rape, incest, or to save the life of the mother.
} 
ruling, thus inferring that the media's framing of a decision, not the actual decision, can cause changes in opinion. This suggests that, although most do not find shifts in opinion following a decision, when changes occur, they often result from other factors surrounding the decision and are not a direct consequence of the actual ruling.

Some scholars, on the other hand, have concluded that Court involvement can be beneficial and can result in increases in public support. Keck (2009) argued that litigation benefited the LGBT community by putting gay rights on the agenda and empowering gay rights advocates. During the process of litigation, states expanded gay rights. They decriminalized sodomy, protected against hate crimes, prohibited employment discrimination, and provided some form of recognition to same-sex couples. Also, public support for gay rights continued to increase during this time. However, Keck also referenced the continued use of lobbying and public education throughout this process, thus suggesting that court decisions were not solely responsible for these gains. This study concludes that litigation in accordance with other variables can lead to the passage of pro-gay policies as well as an increase in public support for gay rights.

\section{$\underline{\text { Demographics and Same-Sex Marriage Policies }}$}

Moreover, researchers have examined the effect of demographic variables on public support for gay rights. They often cite the influence of partisanship, ideology, exposure to the LGBT community, age, sex, and religious affiliation as factors contributing to individual opinion. Scholars studying individual opinion found that the most support for relationship recognition (i.e. civil unions, legal agreements, marriage) came from LGB individuals, Democrats, young adults, females, and the highly educated (Fleischmann and Moyer 2009; Flores 2014). Republicans and older adults, on the other hand, were more likely to oppose 
recognition (Flores 2014; Olson et al 2006). In regards to religion, evangelicals were highly opposed to all forms of recognition, while Jews, Catholics, Non-Protestants, and the unaffiliated were less opposed to relationship recognition (Flores 2014; Fleischmann and Moyer 2009; Olson et al. 2006). These demographic variables have been tied to the passage of gay rights policies in state and local governments. Scholars studying public opinion on the local level found that districts with a large urban population are more likely to support relationship recognition rights, while conservative districts are less supportive of same-sex relationship recognition. In regards to state demographics, Olson et al. (2006) found that conservative states are more likely to support same-sex marriage bans, while liberal states are more likely to oppose them. States with a large Republican population or with a strong evangelical community are more likely support a ban, while states with mostly Democratic representation or with a large LGB population are likely to oppose a ban (Lewis and Seong Soo Oh 2008). These studies find that, because certain demographic groups are more supportive of relationship recognition, the demographic makeup of a state affects public support within that state, which then affects the policies that state passes.

\section{$\underline{\text { Public Opinion and Policies on Gay Rights }}$}

Others have concluded that policies on LGBT rights may not reflect public support, but instead reflect organized interests. Barclay (2010) argued that most rulings of state and federal judges are in line with the expressed preferences of state legislatures and Congress, thus finding little support for President Bush's statement that judges are acting outside the will of the people, communicated through their elected officials. However, some urge that the laws passed by elected officials do not reflect the will of the people. Lax and Phillips (2009) found that new laws and representation may be a result of political mobilization, not public opinion. Conservative 
ideals are overrepresented because of powerful, Religious Right interest groups (Lax and Phillips 2009). They found that policies on adoption, marriage, and sodomy are in line with public opinion (Lax and Phillips 2009). Policies on civil unions, jobs, housing, health, and hate crimes, on the other hand, are more conservative than the majority wants.

However, although these policies may not reflect opinion, evidence has shown that they may influence opinion. Barclay and Flores (2014) found that the persistence of a law within a state affected public support for same-sex marriage. Each year the state maintained a ban, the more the public supported same-sex marriage (Barclay and Flores 2014). The laws of other states also swayed public opinion within a state. An increase in the number of states and, specifically, an increase in the number of neighboring states that allowed same-sex marriage caused an increase in public support within a state (Barclay and Flores 2014). These researchers conclude that public opinion shifts after the passage of a ban on same-sex marriage. Support increases the longer the ban is on the books and continues to increase as other states legalize same-sex marriage.

\section{$\underline{\text { Acquiescence with Court Decisions }}$}

Furthermore, studies have also examined shifts in public opinion resulting from acquiescence with a Court ruling. Researchers have studied the impact of legitimacy on the public's likelihood to accept a Supreme Court decision. Gibson (2012) argued that the public holds the Court in high esteem. Because the public believes that the Court bases its decision on legal reasoning rather than partisan considerations, citizens are more likely to accept its rulings, even if they disagree (Gibson 2012). Some, however, have argued that the residents of the city or state where the case arises from are more reluctant to accept the decision. After the Court ruled in Lamb's Chapelv. Center Moriches Union Free School District, residents in Center Moriches, New York were 
more likely to maintain the same opinion they had before the ruling. In contrast, residents of Suffolk, New York, a neighboring city to Center Moriches, were more likely to defect to the opinion of the Court (Hoekstra and Segal 1996). Hoekstra and Segal (1996) argue that because the residents of Suffolk were not directly affected by the decision, they were more willing to accept it. Because residents of Center Moriches were directly affected by the ruling, they were reluctant to do so. This suggests that, although the Court is seen as legitimate by a vast majority of the public, when they are not directly affected, the public is more accepting of the Court's decision. However, when they are directly affected, the public is more reluctant to accept a ruling.

\section{The Limited Reach of Obergefell}

Consistent with Bishin (2015) and Hoekstra and Segal (1996), I argue that the Obergefell ruling will not have an effect on national public support for same-sex-marriage. However, it will affect support on this issue in the state of Kentucky. I contend that national public support for same-sex marriage will continue to increase modestly following Obergefell. Gaps in support among whites and blacks will remain constant because the disparity between the races is due to differences in religion and religiosity, which will not be affected by the Obergefell ruling. As well, the gap between white evangelicals and white mainline Protestants will remain unchanged because variances between these groups are a result of differences in doctrine, which existed before the ruling, and will not be affected by the ruling. I assert that the gap between Republicans and Democrats on the national level will also remain constant because of the firm stances these parties have maintained on this issue. Partisan framing following the decision will not affect support among these parties because most members were likely exposed to these frames prior to the decision. 
In Kentucky, I maintain that public support will be no higher after Obergefell than it was before. As a result, the gap between support from blacks and support from whites will also remain unchanged. I argue that the gap between support from Republicans and Democrats in Kentucky will increase because of partisan framing. Tea Party leaders will frame the decision as an overreach of power by the federal government, causing Republicans to resent the ruling and, consequently, same-sex marriage. On the other hand, left-leaning media outlets will frame the ruling as a decisive victory in the struggle for equality. This use of the equality frame will lead to an increase in support among Kentucky Democrats. Despite these changes in support among the parties, I argue that the majority of members from both parties will remain opposed to same-sex marriage because of Kentucky's conservative, hyper-religious culture. Therefore, the gap between Republicans and Democrats in Kentucky will be smaller than that of the two national parties.

\section{Variables Influencing Support for Same-Sex Marriage}

[Figure 2 here]

National public support for same-sex marriage has reflected a positive, increasing trend over time (Flores 2014). As Figure 2 indicates, I argue that the variables influencing individual opinion regarding same-sex marriage include religion, exposure to the LGBT community, and media framing. Changes in these variables are responsible for increases in support for same-sex marriage. In regards to religion, the Christian share of the population has decreased over the last decade while the share of unaffiliated adults as well as the share of Non-Christian adults has increased steadily (Pew Research Center June 4- September 30, 2014). ${ }^{2}$ As Flores (2014)

\footnotetext{
${ }^{2}$ The percentage of adults identifying as Christian dropped from $78.4 \%$ in 2007 to $70.6 \%$ in 2014. The percentage of unaffiliated adults increased from $16.1 \%$ to $22.8 \%$. The percentage of Non-Christian adults has increased from $4.7 \%$ to $5.9 \%$.
} 
concluded, Non-Christians and the unaffiliated are more supportive of relationship recognition. I argue that changes in religious affiliation are partly responsible for the increase in nationwide support over time. Moreover, Lewis and Seong Soo Oh (2008) found that the larger the LGB community is within a state, the more support there is for relationship recognition. Consistent with their argument, I assert that more exposure to the LGBT community will lead to more support for same-sex marriage (Figure 2). In recent years, the number of adults that personally know a member of this community has increased (Pew Research May 1-5, 2013). ${ }^{3}$ I contend that the increase in number of people that have friendship of familial ties to LGBT individuals will lead to an increase in support for same-sex marriage. I also assert that changes in media framing of the LGBT community will lead to more support for same-sex marriage. Evidence has shown that media coverage of LGBT individuals as well as the gay rights movement has increased and, along with that increase, the media's depiction of this group as well as the language employed to describe the movement has become more positive (Hackl et al. 2013; Steiner et al. 1993).

I posit that these factors are responsible for increases in support for same-sex marriage. Changes in religion and exposure to the LGBT community occurred prior to Obergefell and will not be changed by the Court's decision in Obergefell. Although Stoutenborough (2006) found that the media's negative depiction of the Court's decision in Lawrence v. Texas led to a decrease in support for homosexual sodomy, the media focused on future implications of the ruling, not the actual ruling. Media outlets argued that it could lead to the legalization of samesex marriage, which led to a decrease in support for homosexual sodomy. Therefore, the actual ruling did not have an effect on opinion; its perceived effects, however, did (Engel 2013). I

\footnotetext{
${ }^{3}$ The percentage of adults personally knowing someone that is gay or lesbian increased from $61 \%$ in 1993 to $87 \%$ in 2013.
} 
contend that this will not occur with the Obergefell decision because the ruling will be seen as the fulfillment of the ultimate goal of the gay rights movement, rather than a means to push for more rights. Therefore, this positive progression in support for same-sex marriage will be interrupted. Furthermore, because I attribute changes in support to the influence of other variables, and not Court decisions, the Obergefell ruling should not have an effect on opinion. Therefore, support for same-sex marriage should continue on its previous trend.

H1: National public support for same-sex marriage will continue to increase modestly after Obergefell.

\section{The Effect of Race and Religiosity}

With respect to race, I argue that the influence of religion and religiosity will account for the gap between whites and blacks. Because the variable causing this disparity is unrelated to Court decisions, I maintain that the gap between the races will remain unchanged following Obergefell. I expect blacks will have the lowest support for same-sex marriage because of the group's strong, religious ties. Whites have proven to have looser ties to religion, and thus should be more accepting of the LGBT community (Gallup Daily tracking survey Religiousness by Race and Ethnic Groups January-May 2011). In regards to support among Latinos, I do not have clear directional expectations because of conflicting indicators. Although the majority of Latinos say that their religious beliefs are an important part of their life, the majority also believe homosexuality should be accepted by society (Pew Hispanic Center 2012). Despite this conflict, nothing suggests that the racial gap in opinion before Obergefell will be changed by the decision in Obergefell. Variables affecting support among blacks, whites, and Latinos are unrelated to Court decisions. Therefore, I argue that gaps in support between the races will not change following the ruling. 
H2: The gap in national public support among whites, blacks, and Latinos will remain unchanged following Obergefell.

\section{Religion and Support for Same-Sex Marriage}

In regards to religion, I expect public support among white mainline Protestants to be greater than that of white evangelicals because of differences in doctrine. Most white mainline denominations now teach a doctrine of inclusion, with many allowing same-sex couples to marry in the church in recent years (United Church of Christ, Episcopal Church, Presbyterian Church (U.S.A.)). In contrast, most evangelicals holdfast to the belief that marriage is a sacred union meant only to be between a man and a woman. In this case as well, I argue that the factors influencing opinion are outside of the realm of the Court. Recent changes in the doctrine of white mainline Protestants occurred prior to Obergefell, suggesting that changes in the gap between white evangelicals and white mainline Protestants occurred prior to the ruling. If this is the case, the gap should remain unchanged in national data following the 2015 ruling.

H3: The gap between support from white evangelicals and support from white mainline Protestants will remain unchanged following Obergefell.

\section{Partisan Differences in Support for Same-Sex Marriage}

In addition, I expect the gap in support between the national parties to remain constant following Obergefell. Both parties have maintained firm stances on this issue, with most Republicans opposed and most Democrats supportive. Leaders in the Republican Party will frame the ruling as judicial lawmaking and as a direct attack on religious liberty. Left-leaning media outlets will frame the ruling as an affirmation of the constitutional rights once denied to same-sex couples, yet granted to heterosexual couples. However, I posit that framing will not affect members on the national level because most members were already exposed to these 
frames before the decision. Unlike what I expect to see on the state level, I argue that most members of the national parties will not be exposed to the state sovereignty frame, seeing that 37 states already legalized same-sex marriage before Obergefell. In view of the fact that party members have likely consumed information utilizing the judicial activism frame, the religious liberty frame, and the equality frame prior to Obergefell, I argue that the ruling will only affirm previously held attitudes toward same-sex marriage.

H4: The gap between support from Republicans and support from Democrats will remain unchanged following Obergefell.

\section{$\underline{\text { Kentucky Exceptionalism }}$}

In contrast to the expected increase in support on the national level, I expect support in Kentucky to be no higher after Obergefell than it was before. Hoekstra and Segal (1996) found that the residents of the city or state that the case arises from are more likely to reject a decision because they are directly affected by it. In Kentucky, the Obergefell decision overturned a constitutional amendment. Therefore, I argue that the decision will be perceived as an infringement upon states' rights and will undermine any prospective progress in opinion. As Rosenberg (1991) asserted, Court involvement in the culture war often leads to stagnation in the public's progression on an issue. In the case of same-sex marriage, I do not expect this be true on the national level because the majority of Americans supported allowing gays and lesbians to marry prior to Obergefell. However, given the conservative, religious culture that is unique to southern states as well as the existing pushback against same-sex marriage, I posit that Court involvement will impede any gains for the LGBT community in the state of Kentucky. State estimates for Kentucky opinion suggest that support for same-sex marriage has reflected an increasing trend over time (Gelman et al. 2010). I argue that this trend will be interrupted by the 
Obergefell ruling. Although support for same-sex marriage has increased slowly in the state, I contend that the decision will halt progression in Kentucky. In regards to race, as seen on the national level, I assert that differences in religiosity between blacks and whites will lead to greater support for same-sex marriage among whites. Again, because these variables are outside of the realm of the Court, the gap between races will remain constant after the decision.

H5: Public support for same-sex marriage in Kentucky will be no higher after Obergefell than it was before.

H6: The gap between support from blacks and support from whites in Kentucky will remain unchanged following Obergefell.

\section{The Effects of Partisan Framing}

Thus far, my hypotheses have predicted that the Court ruling in Obergefell will not have a measurable impact. However, there is one subgroup for whom I do expect to see a difference. Among Republicans and Democrats, I argue that the gap in support will increase following Obergefell due to partisan framing. Republicans in the state will not only view the decision as judicial lawmaking as well as a threat to religious liberty, but will also see it as direct attack on state sovereignty because of partisan framing by Tea Party leaders in the state. The state sovereignty frame has been used by Tea Party members in the past in attempts to overturn Windsor. Representative Weber (R-TX) introduced the State Marriage Defense Act of 2014 in the House, which was cosponsored by Rep. Thomas Massie (R-KY), and was introduced in the Senate by Senator Ted Cruz. It sought to force the federal government to defer to the state's definition of marriage when applying federal laws. This bill was reintroduced by Cruz before the Court announced its decision in Obergefell. I expect these leaders to continue to use this frame following Obergefell. I argue that it will appeal to Kentucky Republicans because the Tea Party 
has a strong presence in the state. Several Tea Party members, who have faced establishmentbacked candidates in their respective primaries (Gov. Matt Bevin, Sen. Rand Paul, Rep. Thomas Massie) were elected. This suggests that the Tea Party movement has gained a significant following in Kentucky and, therefore, framing by its leaders will disproportionately affect Republicans in state. Moreover, I argue that the use of the equality frame will cause an increase in support among some skeptical Democrats. Most Democrats in Kentucky are socially conservative; however, because Democrats are usually more egalitarian than Republicans, the use of the equality frame following the ruling will appeal to them (Gelman 2009; Wildavsky and Dake 1990). This will lead to an increase in support among Democrats in Kentucky. As a result of these factors, I contend the gap between support from Democrats and Republicans will increase following the ruling.

H7: The gap between support from Republicans and support from Democrats in

\section{Kentucky will increase following Obergefell.}

In regards to party differences on this issue, support among Republicans and Democrats in Kentucky will vary slightly. Despite expected changes in support explained above, I still expect the gap between the national Republican Party and the national Democratic Party to be wider than that of the state parties. Although more Democrats will support same-sex marriage, I argue that the majority will remain opposed to it. Recent elections support this assumption. Although most registered voters are Democrats, Kentucky consistently votes for Republican presidential candidates. ${ }^{4}$ Also, Republicans enjoyed a sweeping victory in the 2015 general election and, even Democratic Party leaders in Kentucky often maintain conservative views on marriage. For

\footnotetext{
${ }^{4}$ VOTER REGISTRATION STATISTICS REPORT
} 
example, former Democratic Governor Steve Beshear was the defendant for the two cases arising from Kentucky. These examples suggest that Kentucky Democrats are different from the national party. Therefore, although I expect the gap between the parties to widen following the ruling, because the majority in both parties will remain opposed to same-sex marriage, this gap will remain smaller than that of the national parties.

H8: The gap between support from Republicans and Democrats in Kentucky will be smaller than the gap between Republicans and Democrats on the national level before and after Obergefell.

\section{Measuring Support for Same-Sex Marriage}

Numerous polls have been conducted in order to measure public opinion on the issue of same-sex marriage. However, variations in the question wording, answer choices, and methodologies used in these polls can skew results. These "house effects" can lead to erroneous conclusions about public evolution on this issue. They can also affect findings on the influence of the Obergefell ruling on public opinion regarding same-sex marriage. Therefore, differences in the methodologies utilized in the surveys from the Pew Research Center, the Bluegrass Poll, and the Williams Institute, that are used in this study, are important to highlight. ${ }^{5}$

[Table 1 here]

Table 1 displays the dates, methodologies, number of respondents, question wording, answer choices, and margins of error of the surveys from the Pew Research Center and Bluegrass Poll.

$\underline{\text { National Opinion Data }}$

\footnotetext{
5 Thank you to the Pew Research Center and the Williams Institute for providing the raw data for this study.
} 
Changes in nationwide support for same-sex marriage following Obergefell are measured using data from the Pew Research Center. Pew surveys adults ages 18 and older living in all 50 states. ${ }^{6}$ It utilizes responses from both landlines and cell phones, and numbers are chosen using random digit dialing. ${ }^{7}$ Results are weighted to match the national demographics of gender, age, race, Hispanic ethnicity, education, region, population density, phone status (matching the percentage of people in the U.S. with only a landline, only a cellphone, or both), and relative usage of landlines and cell phones (for those with both). ${ }^{8}$

This study employs data from two surveys conducted by Pew prior to U.S. v. Windsor and Hollingsworth v. Perry (March 13-17, 2013; May 1-5, 2013) and two surveys following Windsor and Perry (February 12-26, 2014; September 2-9, 2014). It also includes one survey before and one survey after Obergefell v. Hodges (May 12-18, 2015; July 14-20, 2015). Respondents in each of the surveys were asked about their opinion regarding same-sex marriage. One limitation to the use of this data is that some participants refused to answer, thus skewing nationwide results on support and opposition to same-sex marriage. Also, the question respondents were asked does not describe the conditions of marriage for same-sex couples. Therefore, those that support allowing gays and lesbians to marry, but withholding some of the benefits of heterosexual marriage (i.e. supporters of civil unions or legal agreements) may be absorbed in the group of supporters of same-sex marriage.

\section{$\underline{\text { Kentucky Opinion Data }}$}

\footnotetext{
${ }^{6}$ Respondents from the February 2015 survey were from the continental U.S.

${ }^{7}$ Interviews are conducted in both English and Spanish. Landline respondents are chosen by asking for the youngest adult male or female who is now at home. Cell phone interviews are conducted with the person who answered the phone.

${ }^{8}$ Demographics are based on data from Census Bureau's American Community Survey and population density is based on data from the Decennial Census. Phone status is based on data from the National Health Survey.
} 
Changes in support in Kentucky are measured using data from the Bluegrass Poll, while state estimates from the Williams Institute are used to examine trends in support over time. Similar to Pew, surveys from the Bluegrass Poll include cellphone and home phone respondents and households are selected using random digit dialing. Also, responses are weighted for age, gender, ethnic origin and region. ${ }^{9}$ However, unlike surveys from Pew, home phone respondents are interviewed by a recorded voice, while cellphone respondents are shown a questionnaire on their smartphone, tablet or other electronic device.

This study utilizes surveys taken from January 30-February 4, 2014, July 18- July 23, 2014, March 3-8, 2015 (before Obergefell) and from July 22-28, 2015 (after Obergefell). With the exception of the July 2015 survey, participants in these surveys gave their opinion regarding same-sex marriage in Kentucky. In the July 2015 survey, respondents were not asked if they favor or oppose allowing gays and lesbians to marry. They were asked if they agree or disagree with the ruling. This difference in question wording following Obergefell presents a problem for this study. The main objective of this project was to test changes in public support for same-sex marriage following Obergefell. Because respondents were not asked if they favor or oppose allowing gays and lesbians to marry following the ruling, I cannot test my hypotheses regarding changes in overall support as well as changes in the gaps in support between blacks and whites and Republicans and Democrats in the state.

Moreover, the language used in the question from the July 2015 survey could lead to erroneous conclusions about opinion regarding the decision among Kentucky residents. Most LGBT allies now use the term "equal marriage." "Gay marriage" is usually used among circles that oppose extending marriage rights to the LGBT community. The use of this language could

\footnotetext{
${ }^{9}$ U.S. Census data were employed for demographics
} 
lead to an overestimation of opposition among Kentuckians. Also, respondents in all of the surveys from the Bluegrass Poll were allowed to answer "not sure.” Again, this allows participants to opt out of sharing their opinion, thus skewing reported results for opinion in Kentucky.

Unlike the data from the Bluegrass Poll, the data from the Williams Institute are state estimates extracted from national polls. National polls were aggregated to create a megapoll and a statistical procedure was employed to decompose the megapoll into state estimates. A regression model was used to estimate how demographic variables affect the likelihood someone supports same-sex marriage. Demographic variables include: age (18-29, 30-44, 45-64, 65+), sex (male and female), race (black and all others), and education (Less than H.S. diploma, H.S. diploma, some college, and college graduate). The results were then post-stratified to match the demographics (age, race, sex, and education) of Kentucky. ${ }^{10}$ The likelihood a person supports same-sex marriage was estimated and then the Census data were used to determine how many people in each state fit that demographic profile. The number of supporters in each state was summed up and divided by the total number of people in that state to find the percentage of people in each state that are supportive of same-sex marriage. The only limitation of these data is that they are yearly, aggregate estimates. Therefore, the data cannot be used to examine changes in opinion before and after Obergefell. However, the data can be used as a robustness test in order to assess the accuracy of the data from the Bluegrass Poll and to examine the trend in support for same-sex marriage in Kentucky over time.

\section{Variables}

\footnotetext{
${ }^{10}$ U.S. Census data were employed for demographics
} 


\section{$\underline{\text { Dependent Variables }}$}

The dependent variables included in this study are national public support for same-sex marriage as well support for same-sex marriage in the state of Kentucky. National public support is observed by measuring changes in the percentage of respondents that answered in favor of same-sex marriage in opinion polls taken by the Pew Research Center. Public support in the state of Kentucky is assessed by measuring changes in the percentage of respondents that answered in favor of same-sex marriage in opinion polls taken by the Bluegrass Poll as well changes in estimates made by the Williams Institute.

Independent Variables

Independent variables affecting support on the national level include time, race, religion, and partisanship. The influence of time is measured using polls conducted from March 2013 to July 2015 (prior to Windsor and Perry and following Obergefell), in order to observe whether these cases as well as other significant events affected support. Changes in the gap in support between white mainline Protestants and white evangelicals account for the effect of religion. The effect of race is measured by observing changes in the gap in support between blacks, whites, and Latinos. Changes in the gap in support between Republicans and Democrats are used to measure the impact of partisanship. The influence of time on the state level is measured using polls conducted from February 2014 to July 2015, in order to observe changes in support in relation to significant events leading up to and following the Obergefell decision. The effects of race and partisanship are also measured on the state level by noting changes in the gaps in support between whites and blacks and Republicans and Democrats.

\section{The Dependency of Court Influence}

[Figure 2 here] 
Figure 2 details significant events leading up to Obergefell $v$. Hodges. It provides a context for the ruling and illustrates the current political climate surrounding Obergefell. Figure 2 includes events leading up to the decision that may have also contributed to changes in support for same-sex marriage. Events include Supreme Court decisions, lower court decisions, and state recognitions of same-sex marriages. Figure 2 also tracks the two cases from Kentucky in order to measure changes in Kentucky opinion following lower court decisions as well as changes following the Supreme Court's decision in Obergefell v. Hodges.

\section{Minimal Effect on Support}

[Figure 3 here]

Before examining the impact of the Obergefell case, it is instructive to look at national public opinion before and after the two earlier Supreme Court marriage decisions. Figure 3 shows an increase in support from March 2013 to May 2013 and from May 2013 to February 2014; however, these data points are not statistically significant from one another. As seen in Figure 3, the error bars for these two data points overlap; therefore, they cannot be said to be statistically different from one another. Therefore, it cannot be concluded that opinion changed. However, it can be concluded that a significant increase in support occurred between March 2013 and February 2014. As seen in Figure 2, during this time the Supreme Court struck down Section 3 of the Defense of Marriage Act in U.S. v. Windsor. It also declared proponents of Proposition 8 did not have standing in Hollingsworth v. Perry. This allowed the appellate court's decision to stand, which struck down California's constitutional amendment proscribing samesex marriage. Also, during this period, same-sex marriage was legalized in Rhode Island, Delaware, Minnesota, New Jersey, Hawaii, and Illinois (Figure 2). Despite positive changes in support, it cannot be concluded that the decisions of the Court were solely responsible. This time 
frame left room for the influence of other variables (exposure to the LGBT community, changes in religion and religiosity, state decisions on this issue, etc.) to influence support for same-sex marriage.

Figure 3 also shows a decrease in support from February 2014 to September 2014. As Figure 2 indicates, during this time period, same-sex marriage was legalized in Oregon and the U.S. Court of Appeals for the $10^{\text {th }}, 4^{\text {th }}$, and $7^{\text {th }}$ Circuits ruled in favor of extending marriage rights to same-sex couples. However, support reported from the September 2014 survey could be underestimated. While the percentage of respondents who answered favorably decreased, the percentage of participants who refused to respond increased. Also, other polls conducted around this time either reported that opinion remained unchanged or decreased slightly, suggesting that these court decisions had a limited effect, if any. ${ }^{11}$

Support also increased between September 2014 and May 2015; during which time the Supreme Court decided not to review the cases from the appellate courts, which had the practical effect of legalizing marriage in these circuits (Figure 2). Also, the U.S. Court of Appeals for the 9th Circuit ruled in favor of same-sex marriage in cases from Idaho and Nevada and the 6th Circuit Court of Appeals upheld same-sex marriage bans. The Supreme Court then granted certiorari to review the 6th Circuit cases (Figure 2). Again, despite positive changes in support, suspicion of the accuracy of the September 2014 poll will also affect conclusions made about increases in support from September 2014 to May 2015. Other polls reported small increases in support, suggesting that judicial action may have had a slight effect on opinion (CBS News/New York Times Poll September 12-15, 2014; April 30, 2015- May 3, 2015). However, in this case as

${ }^{11}$ (CBS News/New York Times Poll February 19-23, 2014, September 12-15, 2014; ABC News/Washington Post Poll. October 9-12, 2014, ABC News/Washington Post Poll. February 27-March 2, 2014; Public Religion Research Institute January 2014, September 2014) 
well, other variables could have affected shifts in support. According to Figure 3, support decreased from May 2015 to July 2015. This decrease in support followed the Supreme Court's decision in Obergefell v. Hodges. However, as their overlapping error bas indicate, these data points are not statistically significant. As a result, it cannot be concluded that support decreased and, therefore, Hypothesis 1 can neither be accepted nor rejected.

\section{The Influence of Attitudes Toward the Court System}

[Figure 4 here]

In regards to race, gaps in support between the races remained constant before and after the ruling, supporting my hypothesis that other factors contribute to this continuous disparity. Figure 4 shows an increase in the gap between white respondents and black respondents from March 2013 to May 2013. This gap remained constant until May 2015. From May 2015 to July 2015, this gap remained unchanged, thus providing support for Hypothesis 2. As I previously argued, Court rulings did not change differences between the races. However, this disparity increases as Court decisions approach. This gap increased from March 2013 to May 2013, preceding Windsor and Perry, and from September 2014 to March 2015, prior to Obergefell. Again, however, support may be underestimated because of the possible inaccuracy of the September poll.

Nonetheless, if these changes exist prior to a landmark decision, this may be a result of attitudinal differences in regards to the justice system. As Gibson (2012) contended, the public holds the Court in high esteem; however, most blacks express discontent with the courts, often feeling marginalized by them. As a landmark Supreme Court case approaches, support from blacks decreases slightly while support from whites increases. Following the decisions, however, 
gaps in support remained constant, justifying my argument that other variables, such as differences in religion and religiosity, account for the gap in support between the races.

Furthermore, the percentage of Latino respondents that answered favorably when asked about same-sex marriage before and after Obergefell was greater than that of blacks, but less than that of whites. These data reflect the conflicting variables previously mentioned. Although the majority of Latino respondents are devout Catholics, the majority also accept homosexuality, suggesting that Latinos have to reconcile these contradictory views. Although some Latinos may accept homosexuality, they may reject extending marriage rights to homosexual couples.

Following the decision, the percentage of Latinos that supported same-sex marriage decreased from 56\% to 55\% (Pew Research Center May 12-18, 2015; July 14-20, 2015). Again, in this case, the gap in support between Latinos and whites and Latinos and blacks remained constant, further affirming my argument that differences are due to other variables, such as religion and religiosity.

The Effect of Partisanship on Religious Groups

[Figure 5 here]

As seen among racial groups, changes in opinion among religious groups occur prior to landmark decisions. Figure 5 indicates a large spike in support from white maimline Preotestants prior to these decisions. Although support among this group may have increased during this time, this spike could have been attributed to other factors. For example, the sample of white mainline Protestants in the March 2013 survey consisted of mostly Republicans, suggesting that support from this group was underestimated.

Figure 5 then shows an increase in the gap following the legalization of same-sex marriage in Oregon and the rulings of the $10^{\text {th }}, 4^{\text {th }}$, and $7^{\text {th }}$ Circuits. As support grows among 
white mainline Protestants, support mostly remains flat among white evangelicals. Support then decreased from February 2014 to September 2014, and increased from September 2014 to May 2015. The September poll may have skewed these results as well. As seen among overall opinion, support likely remained constant during this time, suggesting that lower court decisions as well as Oregon's legalization likely did not have an effect on support from these religious groups. According to Figure 5, the gap in support decreased following Obergefell. However, the majority of white mainline Protestants surveyed in July 2015 were Republicans; therefore, support among this group may have been miscalculated.

Notnetheless, following Obergefell, the gap in support between the two groups likely still decreased, but it may not have decreased as much as Figure 5 indicates. Therefore, Hypothesis 3 can be rejected. However, these data support my contention that white mainline Protestants will be more supportive of same-sex marriage. Even when support among this group hit new lows, it still remained well above that of white evangelicals, suggesting that other variables such as differences in doctrine account for this continuous gap between white mainline Protestants and white evangelicals. These data also suggest that partisanship may be a better indicator of support for same-sex marriage. The majority of respondents in the March 2013 and July 2015 surveys were Republicans. The opposition of Republicans drove down support from white mainline Protestants. This suggests that Republicans that belong to mainline denomiations remain socially conservative. Therefore, an individual's party identification may be a better indicator of their support for same-sex marriage than their religious affiliation.

$\underline{\text { Reactions of Party Members }}$

[Figure 6 here] 
According to Figure 6, the gap in support between Democrats and Republicans decreased from March 2013 to May 2013, prior to U.S. v. Windsor and Hollingsworth v. Perry and following the legalization of same-sex marriage in Rhode Island. The gap then increased between May 2013 and February 2014, during which time same-sex marriage was legalized in Delaware, Minnesota, New Jersey, Hawaii, and Illinois (Figure 2). Support from Democrats increased while support from Republicans mostly remained flat, intimating that, with the exception of Rhode Island, state recognition disproportionately affects Democrats. As more states extend marriage rights to same-sex couples, more Democrats support same-sex marriage.

Figure 6 also shows a decrease between February 2014 and September 2014; and an increase from September 2014 and May 2015. However, because of the possible inaccuracy of the September poll, as seen in overall opinion, support from both groups likely remained constant, suggesting that the actions of the lower courts as well as those of the Supreme Court during this time did not influence support for same-sex marriage. According to Figure 6, the gap between the parties increased between May 2015 and July 2015, immediately following Obergefell; therefore, Hypothesis 4 can be rejected. Support from Republicans decreased while support from Democrats increased following the Court's decision in Obergefell. A possible explanation for the behavior of Republicans and Democrats following the ruling could be the influence of partisan framing. Although I previously argued framing would not affect support among Republicans and Democrats on the national level, I did not consider how much information party members consume. If respondents are low information voters, they may not have been exposed to partisan frames prior to Obergefell. Therefore, exposure to these frames following this highly salient case could account for changes in support.

$\underline{\text { Support for Same-Sex Marriage in Kentucky }}$ 
[Figure 7 here]

As seen on the national level, state data provide inconclusive evidence on changes in support in Kentucky following Obergefell. The Bluegrass Poll reported an increase in support for same-sex marriage from February 2014 to July 2014, coinciding with Attorney General Jack Conway's refusal to continue defending the state's same-sex marriage ban (Figure 2). Also, according to Figure 2, District Court Judge Heyburn ruled that Kentucky must recognize samesex marriages from other states (Bourke v. Beshear) and that Kentucky's ban on same-sex marriage violates the Equal Protection Clause (Love v. Beshear), Bluegrass reported a decrease in support for same-sex marriage from July 2014 to March 2015. During this time, the $6^{\text {th }}$ Circuit Court of Appeals upheld same-sex marriage bans and the Supreme Court granted certiorari to review of all the 6th Circuit cases (Figure 2). However, as Figure 2 indicates, these data points are not statistically significant from one another; therefore, it cannot be concluded that these factors led to a change in support in Kentucky.

Hypothesis 5 cannot be tested using the data from the Bluegrass Poll because of differences in question wording following Obergefell. Respondents in the pre-Obergefell survey (March 2015) were asked if they favor or oppose allowing gays and lesbians to marry in Kentucky. However, respondents in the post-Obergefell survey (July 2015) were asked if they agree or disagree with the decision. Therefore, I cannot measure changes in support for same-sex marriage. When asked about Obergefell, thirty-eight percent of respondents agreed with the decision. Although the majority of those who answered favorably are likely supporters of samesex marriage, public support for same-sex marriage may be lower or higher than $38 \%$. Therefore, Hypothesis 5 can neither be accepted nor rejected because of the flawed question wording in the post-Obergefell poll. 
However, through estimates from the Williams Institute, conclusions can be drawn about changes in opinion in Kentucky over time. Figure 8 shows significant increases in support from 2000 to 2008, 2008 to 2011, and 2011 to 2014. Although Bluegrass reported less support than the estimates of the Williams Institute, these estimates suggest that although opinion has been changing more rapidly, it takes at least three years for significant changes to occur. Therefore, it can be inferred that a Court decision in 2015, a year after the last significant increase, would not change this trend in a significant way.

Moreover, following the decision, three county clerks refused to issue marriage licenses, citing their religious beliefs. One of these clerks, Rowan County's Kim Davis, gained national attention after continuing to refuse to issue licenses despite several court orders to do so following a lawsuit from the ACLU. After Davis was found in contempt of Court, jailed, and released, respondents were asked if she should be required to issue the licenses. Fifty-one percent answered that she should be required (Bluegrass September 22-27, 2015). Following Obergefell, the vast majority of respondents answered that they disagree with the decision. However, following Davis's continued refusal to comply and the media's negative portrayal of her noncompliance, most agreed that she should have to comply. This suggests that although most Kentuckians oppose same-sex marriage and oppose the Obergefell ruling, they are willing to acquiesce. Noncompliance by state officials is seen as defiant. Although most Kentuckians maintain similar beliefs to those of Kim Davis, they respect the Court's decision and believe those charged with the duty to carry out the law should do so despite their religious convictions.

This case opposes the view posited by Hoekstra and Segal (1991). Despite being directly affected by the decision, the reaction of Kentucky residents to Kim Davis's noncompliance shows that they are willing to acquiesce. However, after the Republican victory in the 2015 
election, legislators proposed bills and Governor Matt Bevin issued an executive order aimed at protecting clerks who argue that their religious beliefs prevent them from issuing licenses to same-sex couples. ${ }^{12}$ In view of the fact that most Kentuckians believe Davis should be required to issue licenses to same-sex couples, these initiatives are likely reflective of political countermobilization, not public opinion, thus providing support for Lax and Phillips’s (2009) argument.

$\underline{\text { Race and Resistance to Court Involvement }}$

[Figure 8 here]

Moreover, Kentucky data for whites and blacks also provides some support for the impact of attitudinal differences between the races in regards to the justice system. After district court decisions in Bourke v. Beshear and Love v. Beshear (Figure 2), support among blacks in Kentucky decreased while support among whites in Kentucky increased (Figure 8), thus providing support for previous claims about discontent with the courts among blacks. However, unlike the previous trend, actions of the appellate court and the Supreme Court between July 2014 and March 2015 (Figure 2) led to an increase in support from blacks and a decrease in support from whites (Figure 8). As well, changes in the gap in support following Obergefell cannot be examined because of the July 2015 question wording. Obergefell. Of all white respondents $38 \%$ agreed with the decisions. Of all black respondents, $20 \%$ answered agreed with

\footnotetext{
${ }^{12}$ Gov. Bevin's executive order removes the name of counties and county clerks from marriage licenses. The new license lists at the top of the form only the Commonwealth of Kentucky, not the county or the county clerk and allows an issuing official to sign Chieves 2015) The Kentucky Senate passed a bill creating a two marriage license forms, one for same-sex couples and one for heterosexual couples. One marriage license would designate the "bride" and "groom" and the other would designate "first party" and "second party." The names with the names of the county clerk and deputy clerk removed from both forms (Brammer 2016). The Kentucky House passed a bill that would create a single-form license that allows marriage license applicants to check "bride," "groom" or "spouse" beside their name. Names of county clerk are still not included on this form. Bevin has come out in favor of this bill (Schreiner 2016).
} 
the decisions Again, these numbers do not reflect support for same-sex marriage from whites and blacks because those that agree with the Court's reasoning are absorbed in this group; therefore, Hypothesis 6 can neither be accepted nor rejected.

However, these data provide support for the assertion that blacks are resistance to Court involvement. Although blacks in Kentucky are more supportive of same-sex marriage prior to Obergefell, this support is not reflected in their opinion of the Supreme Court's decision. Despite negative feelings toward the courts, the majority of black respondents stated that Kim Davis should be required to issue the licenses. Fifty-eight percent of blacks answered that she should be required to issue the licenses compared to fifty percent of whites (Bluegrass Poll September 2227, 2015). Although they disagreed with the decision, blacks in Kentucky agreed that it should be carried out. This may be because of a connection to their history, seeing that this case may be reminiscent of backlash they experienced following landmark cases, such as Brown v. Board of Education and Loving v. Virginia. ${ }^{13}$

$\underline{\text { Party Registration/Affiliation and Obergefell Aftermath }}$

[Table 2 here]

Furthermore, the data support my hypothesis that the gap in support between the national parties will be larger than that of the state parties. Table 2 shows the influence of party registration on a person's likelihood to support same-sex marriage. Again, the effect of the

\footnotetext{
${ }^{13}$ Following Brown, schools in southern states closed in order to avoid desegregation. States passed freedom of choice" laws, giving parents the ability to determine which schools their children. White parents chose white schools. Black parents chose black schools in order to protect their children from the violence and intimidation resulting from attending a white school (Ball 2006). States also cut off funding for schools under desegregation orders. States also adopted pupil placement laws in order to use criteria, such as aptitude, psychological fitness, and health, to make school assignment decisions and thus remain segregated. Ten years after Brown II, only 1 percent of black students attended a school with white students (Ball 2006). Following Loving v. Virginia, an interracial couple was denied a marriage license (U.S. v. Brittain). Following this decision, most holdout states relented. However antimiscegenation laws were still on the books in many states. South Carolina and Alabama did not revoke their laws until 1999 and 20000. In 2009, a Louisiana justice of the peace refused to issue a license to an interracial couple, citing concern about the upbringing of the couple's future children (Huffington Post 2009).
} 
Obergefell decision on support for same-sex marriage cannot be measured because of the question wording of the post-Obergefell survey. Therefore, Hypothesis 7 cannot be tested using this data. However, the March 2015 survey provides some justification for Hypothesis 8 . Nineteen percent of Republicans and forty-three percent of Democrats in Kentucky support same-sex marriage, compared to thirty-four percent of Republicans and sixty-five percent of Democrats nationwide (Pew Research Center May 12-18, 2015), thus confirming that the gap in support between the parties is larger on the national level. These data support the assertion that political parties in Kentucky are inherently different than the national parties. Even regarding an issue that has incited a culture war on the national level, there is large consensus among party members in the state, supporting the notion of Kentucky exceptionalism. Although there is a disparity between Kentucky Republicans and Kentucky Democrats, the majority in both parties oppose same-sex marriage, suggesting that the culture of the state caused groups that are often on opposing sides of an issue to view this particular issue in the same way.

Although these data cannot be used to determine whether Obergefell influenced support for same-sex marriage, the data can be used to examine the behavior of party members and party affiliates, thus providing a nuanced explanation of party dynamics. Most groups in this survey behave similarly; more respondents agreed with the decision than supported same-sex marriage and even more believed Davis should be required to issue the licenses (Table 2). However, despite opposition to same-sex marriage and disapproval of the Obergefell ruling, some groups overwhelmingly believed Davis should be required to issue the licenses (registered Democrats, Independents leaning Democrat, Democratic affiliates). The behavior of other groups did not follow this common pattern, with more respondents supporting same-sex marriage than agreeing 
with the decision and even more believing Davis should be required to issue the licenses (Strong Republicans, Independents).

Among registered Democrats and Democratic affiliates, the majority opposed same-sex marriage and the majority disagreed with the Obergefell ruling; however, most believed Kim Davis should be required to issue the licenses (Table 2). This may be due to partisan framing of Davis's actions. These respondents likely consumed information from left-leaning media outlets, which depicted her as a defiant, religious bigot, evading her constitutional duty. Also, these respondents may have condemned her refusal to obey orders given by her own party. ${ }^{14}$ Not only did she defy several court orders, but Davis refused to comply with Governor Beshear's directive, which ordered all Kentucky county clerks to authorize licenses to same-sex couples; she later sued Beshear for not protecting her religious liberty. These factors may have informed attitudes toward Davis among Democratic party members and Democratic affiliates, thus causing these groups to overwhelmingly oppose her actions, despite disapproval of same-sex marriage and the Obergefell ruling.

Among Strong Republicans, the vast majority opposed same-sex marriage and disagreed with the decision; however, more favored same-sex marriage than agreed with the ruling (Table 2). This suggests that some Strong Republicans may accept same-sex marriage, but condemn Court mandated same-sex marriage. In view of the fact that conservatives often champion limited federal government, this group may have agreed with the policy, but not the process. Because the Court legalized same-sex marriage rather than the states, they reject the decision. These data support my argument regarding Tea Party framing. Although I expected the state sovereignty frame to affect all Republicans in the state, resistance to intervention by the federal

\footnotetext{
${ }^{14}$ Davis later joined the GOP.
} 
government may have only influenced attitudes toward Obergefell among those who identify as Strong Republicans. Because registered Republicans, Republican affiliates, and Independents leaning Republican followed the trend seen by most other groups (more agreed with the decision than supported same-sex marriage and even more believed Davis should be required to issue the licenses) resistance to federal intervention seems to only affect the most conservative.

Table 2 also shows the volatility of the opinion of Independents; the majority opposed same-sex marriage, and an even larger percentage disagreed with Obergefell, yet the majority believed Kim Davis should be required to issue the licenses. The fact that Independents are often low information voters could explain this volatility (Magleby 2011). These respondents were likely more susceptible to partisan framing and thus may have viewed the decision as constituting judicial overreach. Also, because they are often uninformed, these respondents may have been unaware of the previous cases and events on the national and state level leading up to Obergefell and, therefore, were resistant to the sweeping change it imposed on Kentucky. Independents leaning Democrat were disproportionately more likely to agree with the decision than they were to support same-sex marriage, compared to registered Democrats and Democratic affiliates (Table 2). This may be due to partisan framing as well. These individuals likely consumed information praising Obergefell as a groundbreaking, civil rights victory for the LGBT community, which could have informed attitudes toward the decision.

However, despite variations among these groups, acceptance of the decision as well as reactions to Kim Davis among all of the groups suggests that party members and affiliates are willing to accept a decision even if they disapprove of same-sex marriage. Among most groups, more respondents agreed with decision compared to the amount that support same-sex marriage, and, even more reject Davis's actions This pattern suggests that most are not just willing to 
accept the decision, but condemn those who refuse to carry it out. Even groups that mostly oppose same-sex marriage, Obergefell, and support Kim Davis follow this pattern, suggesting that even some of the most reluctant are willing to acquiesce, thus further providing contradictory evidence to the findings of Hoekstra and Segal (1996).

\section{Conclusion}

This project sought to examine the relationship between Court decisions and public opinion. My main objective was to investigate whether court decisions on culture war issues affect public opinion regarding these issues by measuring changes in support for same-sex marriage following Obergefell $v$. Hodges. I also sought to measure changes in support in Kentucky in order to determine whether Court decisions have a greater effect on the opinion of the individuals that are directly affected by them. By observing changes in the gaps in support between racial groups, religious groups, and parties, I intended to examine whether any of these groups are disproportionately affected by Court involvement.

Because of data limitations, however, I was unable to test my hypotheses regarding changes in support among Kentuckians. I was unable to measure the effect of the Obergefell ruling on support for same-sex marriage in Kentucky. However, I was able to draw some conclusions based on state reactions to the decision. Contrary to my expectations, the majority of Kentuckians were willing to accept the ruling and believe it should be carried out. Despite widespread opposition to same-sex marriage and disapproval of the Obergefell ruling, the majority of Kentucky respondents condemned the actions of Kim Davis. This suggests that although they disagree with the decision, they are willing to acquiesce. Despite disapproval, noncompliance with a Court ruling is condemned by the majority. The reactions of residents of the state to Kim Davis' actions oppose the conclusion made by Hoekstra and Segal (1996) who 
stated that those who are directly affected by a decision are more likely to reject it. This willingness to acquiesce despite widespread disapproval is also reflected in the opinion of party members and affiliates and racial groups in the state. Examining the behavior of blacks and whites in the state before and after Court decisions provides support Gibson's (2012) argument concerning discontent with the justice system among blacks. However, it also shows the black community's aversion to infringements of rights granted to minority groups. Furthermore, measuring gaps in support between Republicans and Democrats on the national and state level, supports my hypothesis that this gap is wider on the national level because the majority in Kentucky remain opposed to same-sex marriage, thus supporting the notion of Kentucky exceptionalism. Observing party dynamics further affirms the assertion that Kentuckians are willing to acquiesce. Although some groups have somewhat disparate reactions, most follow a similar pattern, with more members accepting Obergefell than supporting same-sex marriage and even more condemning Kim Davis' actions. Even among groups that are highly opposed to same-se marriage, this rings true, suggesting that, despite disapproval, residents are willing to accept the Obergefell decision and believe it should be implemented.

On the national level, changes in support for same-sex marriage following Obergefell could not be determined because the data point following the ruling did not reach significance. However, evidence shows that Court decisions precede changes in support. Evidence shows that the Court's decision in U.S. v. Windsor and Hollingsworth v. Perry as well as other lower court decisions occur prior to minor shifts in support for same-sex marriage. However, I cannot conclude that these decisions caused shifts in opinion. In fact, the amount of time between the polls preceding and following Court rulings leaves room for the influence of other variables. As I expected, the gaps in support between whites, Latinos, and blacks remained constant following 
Obergefell, suggesting that the decision did not affect disparities among the groups and supporting my argument that differences in religion and religiosity drive these disparities. However, the gap between whites and blacks prior to landmark decisions widened, supporting the assertion that blacks are disproportionately resistant to Court involvement. Furthermore, contrary to my expectations, the gap between Republicans and Democrats widened following Obergefell, suggesting that Court decisions can spur partisan division. Among white evangelicals and white mainline Protestants, the gap in support for same-sex marriage decreased following Obergefell; however, party identification of the respondents used in the survey may have contributed to this decrease, suggesting that partisanship may be a better indicator of support for same-sex marriage than religious affiliation.

[Figure 9]

After conducting this research, I posit a similar view to that of Rosenberg (1991). Although I find that Court decisions precede changes in support for same-sex marriage, shifts in support were minute and could have been caused by other factors. Therefore, I conclude that it is unlikely to Court decisions are responsible for shifts in support. Figure 9 shows my prediction regarding consequences following Court involvement in the culture war. I argue that public opinion, ideology, and precedent inform Court decisions. Following these rulings, the opposition mobilizes, leading to changes in political representation. Elected officials will reflect the opinion of the opposition, which will lead to the passage of policies aimed at undermining the Court's decision. This change in representation will lead to new judicial appointments. These appointees will reflect the ideology of the President that nominated them, who already represents the opposition. New legislation will be litigated and, because of the change in the Court's composition, there will be a shift in the ideological tenor of the Court, which will lead to 
modified precedent. During this process, public support will decline due to public education resulting from opposition mobilization.

At least on the state level, this process has already started. The Court strategically legalized same-sex marriage nationwide by granting certiorari to the $6^{\text {th }}$ Circuit cases. Not only did the vast majority of Americans support same-sex marriage, but 37 states had already legalized same-sex marriage prior to Obergefell, suggesting that there was large consensus on this issue and a Court decision would not impose sweeping change on most citizens. Furthermore, four liberal justices along with a swing justice who has openly expressed support for the gay rights movement made up the majority in Obergefell. Also, the Court had already set precedent regarding LGBT rights with its decisions in Lawrence and Windsor, whose majority opinions were also written by Justice Kennedy. After the decision, the conservative opposition mobilized, rallying behind Kim Davis. Conservative politicians rallied around her as well, praising her bravery, condemning the federal involvement in marriage, and vowing to protect religious liberty.

In Kentucky, after Bevin's win and the Republicans sweeping victory, laws were proposed that were not only aimed at protecting the religious liberties of county clerks, but could also undermine previous gains for the LGBT community. For example, the Kentucky Senate passed SB 180, which allows businesses to deny services to individuals if they deem that service a violation of their religious beliefs (Chieves 2016). Other states have enacted similar laws. For example, North Carolina passed a law preventing local governments from passing ordinances allowing transgender people to use the bathroom corresponding to the gender with they identify with (Kopan and Scott 2016). I expect this backlash to continue, thus rolling back any gains the 
LGBT community once enjoyed and possibly spilling over into other social movements (i.e. civil rights and women's rights).

Future research could test my prediction regarding Court involvement in the culture war by measuring changes in support for same-sex marriage and observing backlash following Obergefell over a longer period of time. Research could also test my hypotheses concerning the effect of media framing, exposure to the LGBT community, and religion on support for same-sex marriage. Studies could track a group of people over time to see if their exposure to the LGBT community has changed and how that has changed attitudes toward same-sex marriage.

Researchers could also test changes in support for same-sex marriage after exposing individuals to traditional/moral frames or equality frames communicated in news articles or after watching shows like Ellen or Modern Family in order to test whether the media's depiction of the LGBT community affects support for same-sex marriage. 


\section{Works Cited}

Ball, Carlos A. "The Backlash Thesis and Same-Sex Marriage: Learning from Brown v. Board of Education and Its Aftermath." William \& Mary Bill of Rights Journal 14 (2006).

Barclay, Scott and Flores, Andrew R. "Backlash, Consensus, or Naturalization: The Impact of Policy Shift on Subsequent Public Opinion Levels.” Western Political Science Association Panel 17. 01 - Public Opinion on LGBT Issues Seattle, WA. Print.

Barclay, Scott. "In search of judicial activism in the same-sex marriage cases: Sorting the evidence from courts, legislatures, initiatives and amendments." Perspectives on Politics 8.01 (2010): 111-126.

Bartels, Brandon L., and Christopher D. Johnston. "On the ideological foundations of Supreme Court legitimacy in the American public." American Journal of Political Science 57.1 (2013): 184-199.

Bishin, Benjamin G., et al. "Opinion Backlash and Public Attitudes: Are Political Advances in Gay Rights Counterproductive?" American Journal of Political Science (2015).

Blake, Judith. "The Supreme Court's abortion decisions and public opinion in the United States." Population and Development Review (1977): 45-62.

Bluegrass Poll. "KY opposition to gay marriage grows, poll finds." Lexington, KY Lexington Herald-Leader, The Courier-Journal, WKYT-TV and WHAS-TV, 2015. Web. 29 Feb. 2015. http://media.kentucky.com/smedia/2015/03/10/20/47/cU3An.So.79.pdf\#storylinrelastB Bluegrass Poll. "Majority disagree with same-sex marriage ruling." Lexington, KY Lexington Herald-Leader, The Courier-Journal, WKYT-TV and WHAS-TV, 2015. Web. 29 Feb. 2015. http://media.kentucky.com/smedia/2015/08/03/17/55/SrOq.So.79.pdf 
Bluegrass Poll. "Majority of Ky. voters think Kim Davis should issue marriage licenses."

Lexington, KY Lexington Herald-Leader, The Courier-Journal, WKYT-TV and WHASTV, 2015. Web. 29 Feb. 2015.

http://media.graytvinc.com/documents/Complete+Bluegrass+Poll+results+fromOctober+ 1.pdf

Bluegrass Poll. "Opposition to same-sex marriage in Kentucky down 5 points since February." Lexington, KY Lexington Herald-Leader, The Courier-Journal, WKYT-TV and WHASTV, 2014. Web. 29 Feb. 2015 http://media.kentucky.com/smedia/2014/07/29/17/29/1pavMD.So.79.pdf\#storylink=relast Brammer, Jack. "Kentucky Senate Approves Bill to Require Two Different Marriage License Forms." Kentucky. Herald Leader, 18 Feb. 2016. Web. 31 Mar. 2016.

Chieves, Johm. "Bevin Orders Marriage License Changes; Reverses Beshear on Felon Voting Rights, Minimum Wage." Kentucky. Herald Leader, 22 Dec. 2015. Web. 30 Mar. 2016.

Chieves, John. "Bill Would Let Businesses Refuse to Serve Gay Customers for Reasons of Faith." Kentucky. Herald Leader, 25 Feb. 2016. Web. 31 Mar. 2016.

Engel, Stephen M. "Frame spillover: Media framing and public opinion of a multifaceted LGBT rights agenda." Law \& Social Inquiry 38.2 (2013): 403-441.

Fleischmann, Arnold, and Laura Moyer. "Competing Social Movements and Local Political Culture: Voting on Ballot Propositions to Ban Same-Sex Marriage in the US States*." Social Science Quarterly 90.1 (2009): 134-149.

Flores, Andrew and Barclay, Scott April 2015. Trends in Public Support for Marriage for Same Sex Couples by State (n.d.): n. pag. Web. 29 Feb. 2015. 
http://williamsinstitute.law.ucla.edu/wp-content/uploads/Trends-in-Public-Support-for Same-Sex-Marriage-2004-2014.pdf

Flores, Andrew November 2014. National Trends in Public Opinion on LGBT Rights in the United States (n.d.): n. pag. Web. 29 Feb. 2015. http://williamsinstitute.law.ucla.edu/wp-content/uploads/POP-natl-trends-nov-2014.pdf

Flores, Andrew R. "Reexamining Context and Same-Sex Marriage: The Effect of Demography on Public Support for Same-Sex Relationship Recognition." International Journal of Public Opinion Research 26.3 (2014): 283-300.

Gelman, Andrew, Jeffrey Lax, and Justin Phillips. "Support for Same-Sex Marriage, State by State." The New York Times. The New York Times, 21 Aug. 2010.Web. 20 Mar. 2016.

Gelman, Andrew. Red state, blue state, rich state, poor state: Why Americans vote the way they do. Princeton University Press, 2009.

Gibson, James L. "Can the Supreme Court Survive a Health-Care Decision?" Pacific Standard n.d.: n. pag. Pacific Standard. 26 Mar. 2012. Web. 13 Sept. 2015.

Hoekstra, Valerie J., and Jeffrey A. Segal. "The shepherding of local public opinion: The Supreme Court and Lamb's Chapel." The Journal of Politics 58.04 (1996): 10791102.

Jones, Jeffrey M. "Fewer in U.S. Want Government to Promote Traditional Values." Gallup Poll. N.p., 30 Sept. 2015. Web. 30 Mar. 2016.

Keck, Thomas M. "Beyond backlash: Assessing the impact of judicial decisions on LGBT rights." Law \& Society Review 43.1 (2009): 151-186.

Kopan, Tal. "North Carolina Governor Signs Controversial LGBT Bill." CNN. Cable News Network, 24 Mar. 2016. Web. 31 Mar. 2016.

Lax, Jeffrey R., and Justin H. Phillips. "Gay rights in the states: Public opinion and policy 
responsiveness." American Political Science Review 103.03 (2009): 367-386.

Lewis, Gregory B., and Seong Soo Oh. "Public opinion and state action on same-sex marriage." State \& Local Government Review (2008): 42-53.

Magleby, David B., Candice J. Nelson, and Mark C. Westlye. "The myth of the independent voter revisited." Facing the challenge of democracy: Explorations in the analysis of public opinion and political participation (2011): 238-266.

Pew Hispanic Center 2012 National Survey of Latinos (Data file and code book). Washington, DC: Pew Research Center, 2012. Web. 29 Feb 2015. http://www.pewhispanic.org/category/datasets/?download=20420

Pew Research Center. In Gay Marriage Debate, Both Supporters and Opponents See Legal Recognition as 'Inevitable' (Data file and code book). Washington, DC: Pew Research Center, 2013. Web. 29 Feb 2015. http://www.people-press.org/category/datasets/?download=20052642

Pew Research Center. U.S. Public Becoming Less Religious Modest Drop in Overall Rates of Belief and Practice, but Religiously Affiliated Americans Are as Observant as Before. Washington, DC: Pew Research Center, 2015. Web. 29 Feb 2015. http://www.pewforum.org/2015/11/03/u-s-public-becoming-less-religious/

Pew Research Center. Growing Support for Gay Marriage: Changed Minds and Changing Demographics (Data file and code book). Washington, DC. Pew Research Center, 2013. Web. 29 Feb 2015. http://www.people-press.org/category/datasets/?download=20050963 Pew Research Center. Millennials in Adulthood Detached from Institutions, Networked with Friends. Pew Research Center, 2014. Web. 29 Feb 2015. http://pewsocialtrends.org/2014/03/07/millennials-in-adulthood. 
Pew Research Center. Negative Views of Supreme Court at Record High, Driven by

Republican Dissatisfaction (Data file and code book). Pew Research Center, 2015. Web.

29 Feb 2015. http://people-press.org/category/datasets/?download=20059299

Pew Research Center. Public Sees Religion's Influence Waning: Growing Appetite for

Religion in Politics. Pew Research Center, 2014. Web. 29 Feb 2015.

http://pewforum.org/2014/09/22/section-3-social-political-issues/

Pew Research Center. Support for Same-Sex Marriage at Record High, but Key Segments

Remain Opposed (Data file and code book). Pew Research Center, 2015. Web. 29Feb

2015. http://people-press.org/category/datasets/?download=20058139

Post, Huffington. "Interracial Couple Denied Marriage License by Louisiana Justice Of The

Peace." (2009).

Rosenberg Gerald, N. "The hollow hope: Can courts bring about social change." The University of Chicago, Chicago and London (1991).

Schreiner, Bruce. "Kentucky House Passes Bill for 1 Marriage License Form." ABC News. ABC News Network, 25 Mar. 2016. Web. 30 Mar. 2016.

Steiner, Linda, Fred Fejes, and Kevin Petrich. "Invisibility, homophobia and heterosexism: Lesbians, gays and the media." (1993): 395-422.

Stoutenborough, James W., Donald P. Haider-Markel, and Mahalley D. Allen. "Reassessing the impact of Supreme Court decisions on public opinion: Gay civil rights cases." Political Research Quarterly 59.3 (2006): 419-433.

Wildavsky, Aaron, and Karl Dake. "Theories of risk perception: Who fears what and why?" Daedalus (1990): 41-60. 
Yetter, Deborah. "Kim Davis Marriage License Bill Clears Senate." The Courier-Journal. 18 Feb. 2016. Web. 30 Mar. 2016. 
Table 1: Description of Polls

\begin{tabular}{|c|c|c|c|c|}
\hline Poll Source & $\begin{array}{l}\text { Date of Poll/ } \\
\text { Methodology }\end{array}$ & $\begin{array}{l}\text { Number of } \\
\text { Respondents/ } \\
\text { Margin of } \\
\text { Error }\end{array}$ & Question Wording & Answer Categories \\
\hline \multirow[t]{6}{*}{$\begin{array}{l}\text { Pew Research } \\
\text { Center }\end{array}$} & $\begin{array}{l}\text { March 13-17, } \\
2013 \\
\text { Random digit } \\
\text { dialing }\end{array}$ & $\begin{array}{l}1,501 \text { adults } \\
\pm 2.9 \% \text { with a } \\
95 \% \\
\text { confidence } \\
\text { level }\end{array}$ & $\begin{array}{l}\text { Do you strongly favor, } \\
\text { favor, oppose, or strongly } \\
\text { oppose allowing gays and } \\
\text { lesbians to marry legally? }\end{array}$ & $\begin{array}{l}\text { strongly favor } \\
\text { favor } \\
\text { strongly oppose } \\
\text { oppose } \\
\text { don't know/refused }\end{array}$ \\
\hline & May $1-5,2013$ & $\begin{array}{l}1,504 \text { adults } \\
\pm 2.9 \% \text { with a } \\
95 \% \\
\text { confidence } \\
\text { level }\end{array}$ & $\begin{array}{l}\text { Do you strongly favor, } \\
\text { favor, oppose, or strongly } \\
\text { oppose allowing gays and } \\
\text { lesbians to marry legally? }\end{array}$ & $\begin{array}{l}\text { strongly favor } \\
\text { favor } \\
\text { strongly oppose } \\
\text { oppose } \\
\text { don't know/refused }\end{array}$ \\
\hline & $\begin{array}{l}\text { February 12- } \\
26,2014 \\
\text { Random digit } \\
\text { dialing }\end{array}$ & $\begin{array}{l}3,338 \text { adults } \\
\pm 2.0 \% \text { with a } \\
95 \% \\
\text { confidence } \\
\text { level }\end{array}$ & $\begin{array}{l}\text { Do you strongly favor, } \\
\text { favor, oppose, or strongly } \\
\text { oppose allowing gays and } \\
\text { lesbians to marry legally? }\end{array}$ & $\begin{array}{l}\text { strongly favor } \\
\text { favor } \\
\text { strongly oppose } \\
\text { oppose } \\
\text { don't know/refused }\end{array}$ \\
\hline & $\begin{array}{l}\text { September 2- } \\
9,2014 \\
\text { Random digit } \\
\text { dialing }\end{array}$ & $\begin{array}{l}2,002 \text { adults } \\
\pm 2.5 \% \text { with a } \\
95 \% \\
\text { confidence } \\
\text { level }\end{array}$ & $\begin{array}{l}\text { Do you strongly favor, } \\
\text { favor, oppose, or strongly } \\
\text { oppose allowing gays and } \\
\text { lesbians to marry legally? }\end{array}$ & $\begin{array}{l}\text { strongly favor } \\
\text { favor } \\
\text { strongly oppose } \\
\text { oppose } \\
\text { don't know/refused }\end{array}$ \\
\hline & $\begin{array}{l}\text { May 12-18, } \\
2015 \\
\text { Random digit } \\
\text { dialing }\end{array}$ & $\begin{array}{l}2,002 \text { adults } \\
\pm 2.5 \% \text { with a } \\
95 \% \\
\text { confidence } \\
\text { level }\end{array}$ & $\begin{array}{l}\text { Do you strongly favor, } \\
\text { favor, oppose, or strongly } \\
\text { oppose allowing gays and } \\
\text { lesbians to marry legally? }\end{array}$ & $\begin{array}{l}\text { strongly favor } \\
\text { favor } \\
\text { strongly oppose } \\
\text { oppose } \\
\text { don't know/refused }\end{array}$ \\
\hline & $\begin{array}{l}\text { July 14-20, } \\
2015 \\
\text { Random digit } \\
\text { dialing }\end{array}$ & $\begin{array}{l}2,002 \text { adults } \\
\pm 2.5 \% \text { with a } \\
95 \% \\
\text { confidence } \\
\text { level }\end{array}$ & $\begin{array}{l}\text { Do you strongly favor, } \\
\text { favor, oppose, or strongly } \\
\text { oppose allowing gays and } \\
\text { lesbians to marry legally? }\end{array}$ & $\begin{array}{l}\text { strongly favor } \\
\text { favor } \\
\text { strongly oppose } \\
\text { oppose } \\
\text { don't know/refused }\end{array}$ \\
\hline
\end{tabular}




\begin{tabular}{|c|c|c|c|c|}
\hline \multirow[t]{4}{*}{ Bluegrass Poll } & $\begin{array}{l}\text { January 30- } \\
\text { February 4, } \\
2014 \\
\text { Questionnaire- } \\
\text { cell phones } \\
\text { Random digit } \\
\text { dialing- home } \\
\text { phones }\end{array}$ & $\begin{array}{l}1,200 \text { adults } \\
\pm 3 \% \text { with a } \\
95 \% \\
\text { confidence } \\
\text { level }\end{array}$ & $\begin{array}{l}\text { Do you favor or oppose } \\
\text { allowing gays and lesbians } \\
\text { to marry in Kentucky? }\end{array}$ & $\begin{array}{l}\text { favor } \\
\text { oppose } \\
\text { not sure }\end{array}$ \\
\hline & $\begin{array}{l}\text { July 18- July } \\
23,2014 \\
\text { Questionnaire- } \\
\text { cell phones } \\
\text { Random digit } \\
\text { dialing- home } \\
\text { phones }\end{array}$ & $\begin{array}{l}800 \text { adults } \\
\pm 3.7 \% \text { with a } \\
95 \% \\
\text { confidence } \\
\text { level }\end{array}$ & $\begin{array}{l}\text { Do you favor or oppose } \\
\text { allowing gays and lesbians } \\
\text { to marry in Kentucky? }\end{array}$ & $\begin{array}{l}\text { favor } \\
\text { oppose } \\
\text { not sure }\end{array}$ \\
\hline & $\begin{array}{l}\text { March 3-8, } \\
2015 \\
\text { hones } \\
\text { Random digit } \\
\text { dialing- home } \\
\text { phones }\end{array}$ & $\begin{array}{l}2,002 \text { adults } \\
\pm 2.3 \text { with a } \\
95 \% \\
\text { confidence } \\
\text { level }\end{array}$ & $\begin{array}{l}\text { Do you favor or oppose } \\
\text { allowing gays and lesbians } \\
\text { to marry in Kentucky? }\end{array}$ & $\begin{array}{l}\text { favor } \\
\text { oppose } \\
\text { not sure }\end{array}$ \\
\hline & $\begin{array}{l}\text { July 22-28, } \\
2015 \\
\text { Questionnaire- } \\
\text { cell phones } \\
\text { Random digit } \\
\text { dialing- home } \\
\text { phones }\end{array}$ & $\begin{array}{l}1,000 \text { adults } \\
\pm 3.4 \text { with a } \\
95 \% \\
\text { confidence } \\
\text { level }\end{array}$ & $\begin{array}{l}\text { Do you agree or disagree } \\
\text { with the U.S. Supreme } \\
\text { Court's recent ruling which } \\
\text { made gay marriage legal } \\
\text { nationwide? }\end{array}$ & $\begin{array}{l}\text { agree } \\
\text { disagree } \\
\text { not sure }\end{array}$ \\
\hline
\end{tabular}


Table 2: Party Registration/Affiliation and Support for Same-Sex Marriage and Opinion on Issuing Marriage Licenses

\begin{tabular}{|c|c|c|c|c|c|c|c|c|c|}
\hline \multicolumn{3}{|c|}{ Party Registration } & \multicolumn{7}{|c|}{ Party Affiliation } \\
\hline & $\begin{array}{l}\operatorname{Re} \\
\text { ps. }\end{array}$ & Dems. & $\begin{array}{l}\text { Strong } \\
\text { Rep. }\end{array}$ & Rep. & $\begin{array}{l}\text { Ind. } \\
\text { lean } \\
\text { Rep. }\end{array}$ & Ind. & $\begin{array}{l}\text { Ind. } \\
\text { lean } \\
\text { Dem. }\end{array}$ & Dem. & $\begin{array}{l}\text { Strong } \\
\text { Dem. }\end{array}$ \\
\hline $\begin{array}{l}\text { March } \\
2015 \\
\text { (before } \\
\text { Obergefell) }\end{array}$ & 19 & 43 & 10 & 17 & 27 & 35 & 49 & 44 & 64 \\
\hline $\begin{array}{l}\text { July } \\
2015 \\
\text { (after } \\
\text { Obergefell) }\end{array}$ & 23 & 47 & 5 & 23 & 30 & 27 & 62 & 48 & 62 \\
\hline \multicolumn{10}{|c|}{ (higher values indicate support for Davis issuing licenses) } \\
\hline Sept. 2015 & 35 & 62 & 24 & 33 & 37 & 54 & 79 & 65 & 77 \\
\hline
\end{tabular}

Notes: Data are drawn from the Bluegrass Poll (March 2015, July 2015, September 2015). In March 2015, respondents were asked, "Do you favor oppose allowing gays and lesbians to marry in Kentucky? In July 2015, respondents were asked "Do you agree or disagree with the U.S. Supreme Court's recent ruling which made gay marriage legal nationwide?” In September 2015, respondents were told, "Rowan County Clerk Kim Davis has refused to issue marriage licenses to gay and lesbian couples, saying she objects on religious grounds. Do you think she should or should not be required to issue them?" 
Figure 1

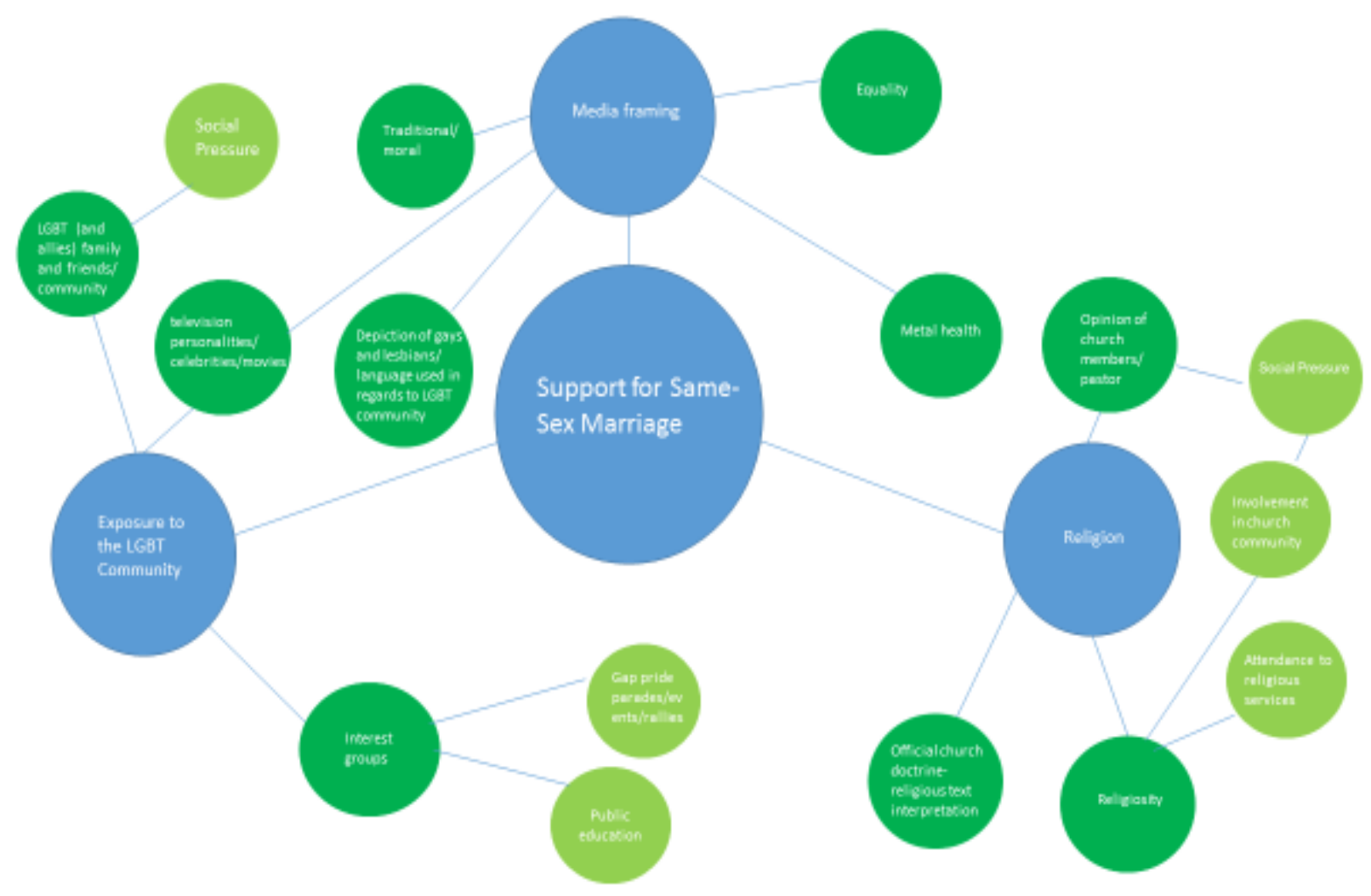


Figure 2

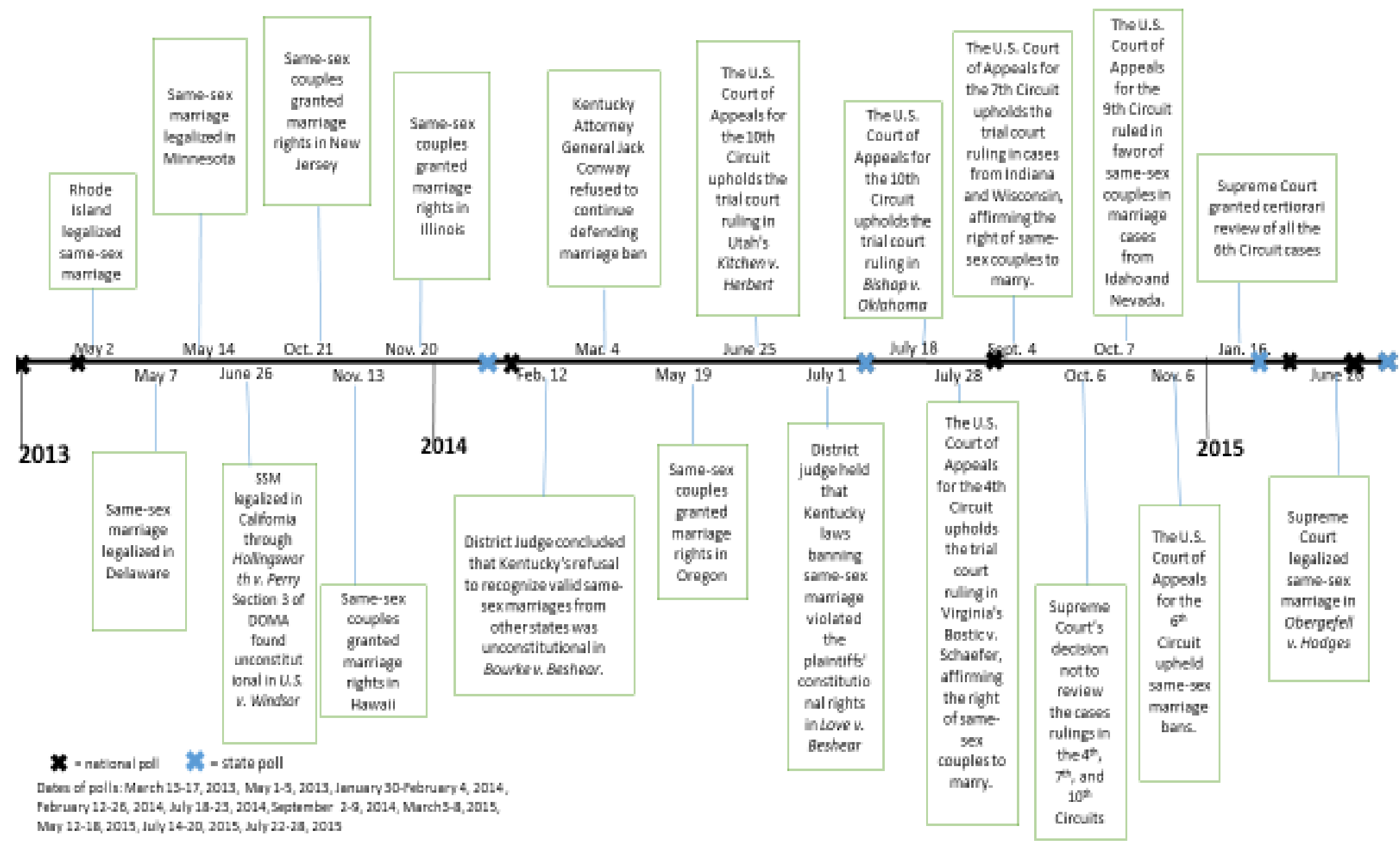


Figure 3

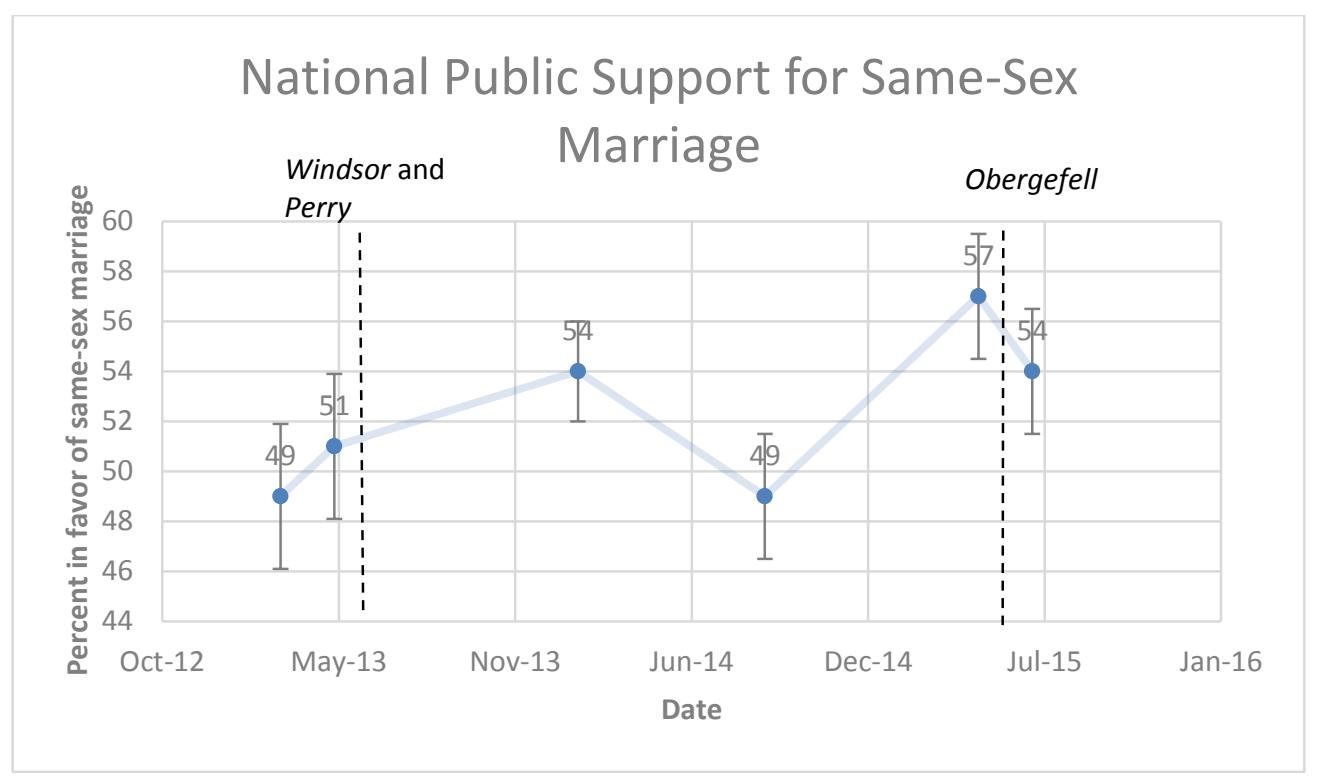

Notes: Data are drawn from the Pew Research Center (March 2013 through July 2015). Respondents were asked, "Do you strongly favor, favor, oppose, or strongly oppose allowing gays and lesbians to marry legally?" 
Figure 4

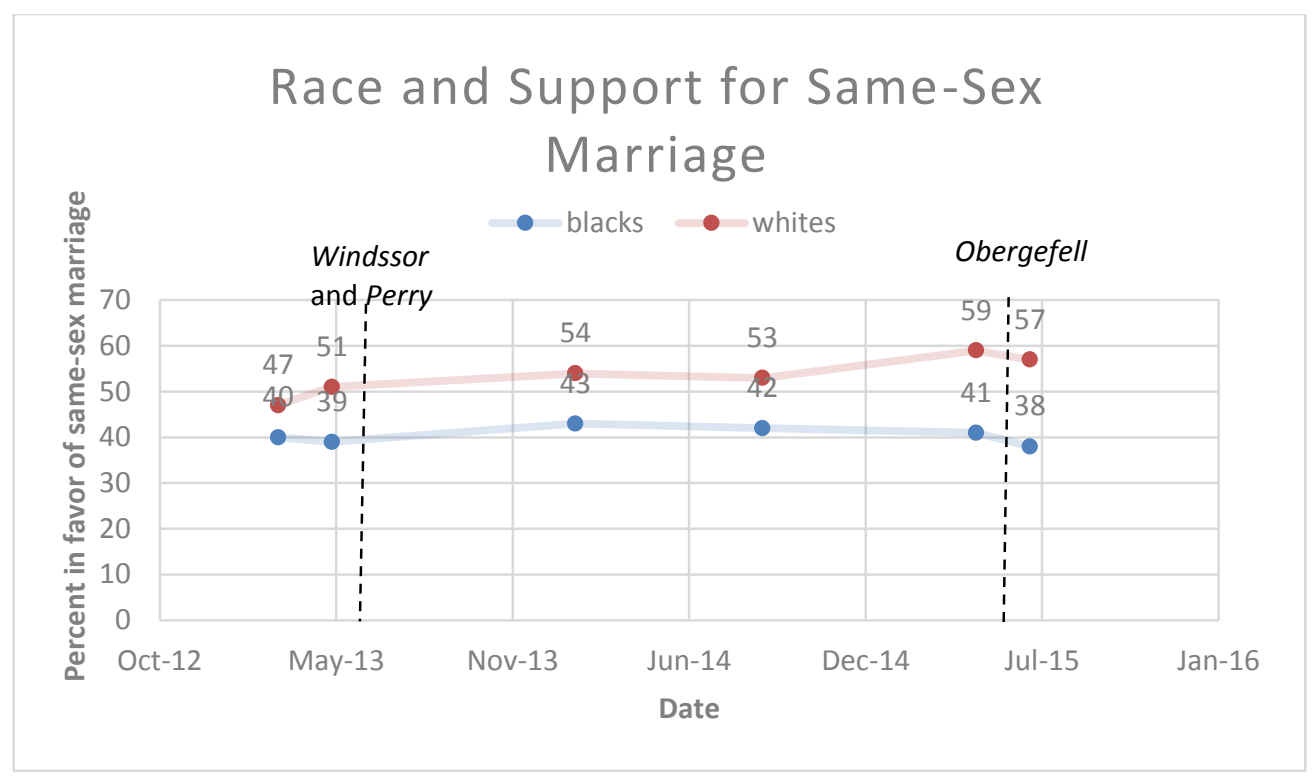

Notes: Data are drawn from the Pew Research Center (March 2013 through July 2015). Respondents were asked, "Do you strongly favor, favor, oppose, or strongly oppose allowing gays and lesbians to marry legally?" 
Figure 5

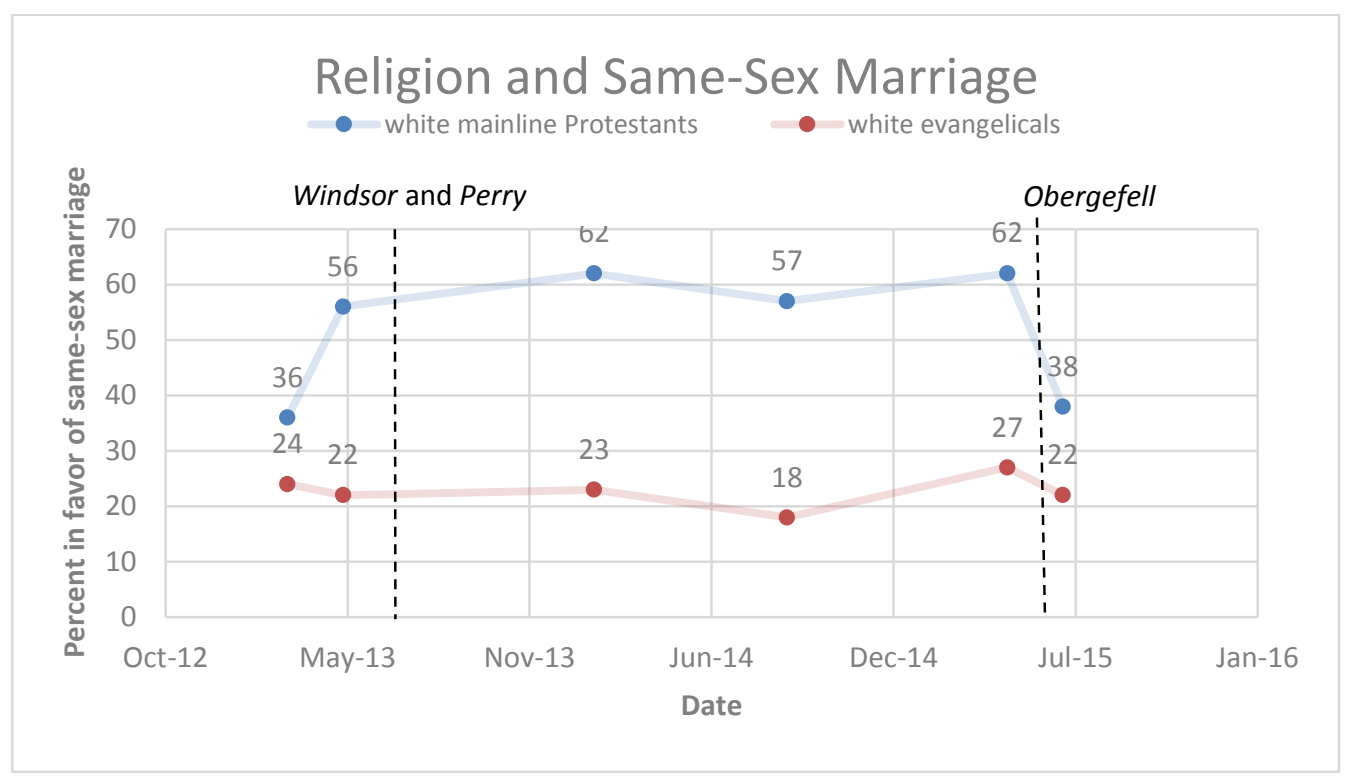

Notes: Data are drawn from the Pew Research Center (March 2013 through July 2015). Respondents were asked, "Do you strongly favor, favor, oppose, or strongly oppose allowing gays and lesbians to marry legally?" 


\section{Figure 6}

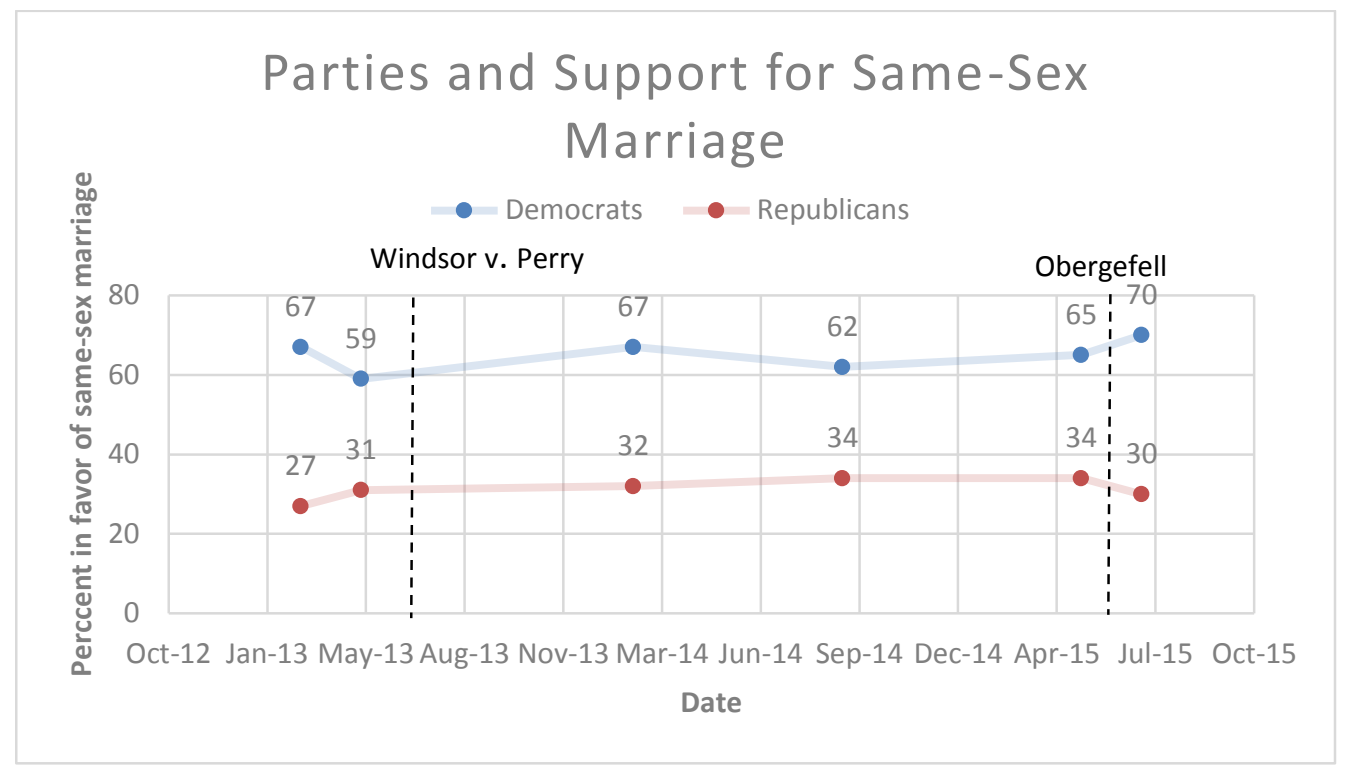

Notes: Data are drawn ${ }^{r} \begin{array}{rr}n & n\end{array} \quad$ ch Center (March 2013 through July 2015). Respondents were aske_., Windsor and Perry a avor, favor, oppose, or strongly oppose allowing gays and lesbians to marry legally?" 


\section{Figure 7}

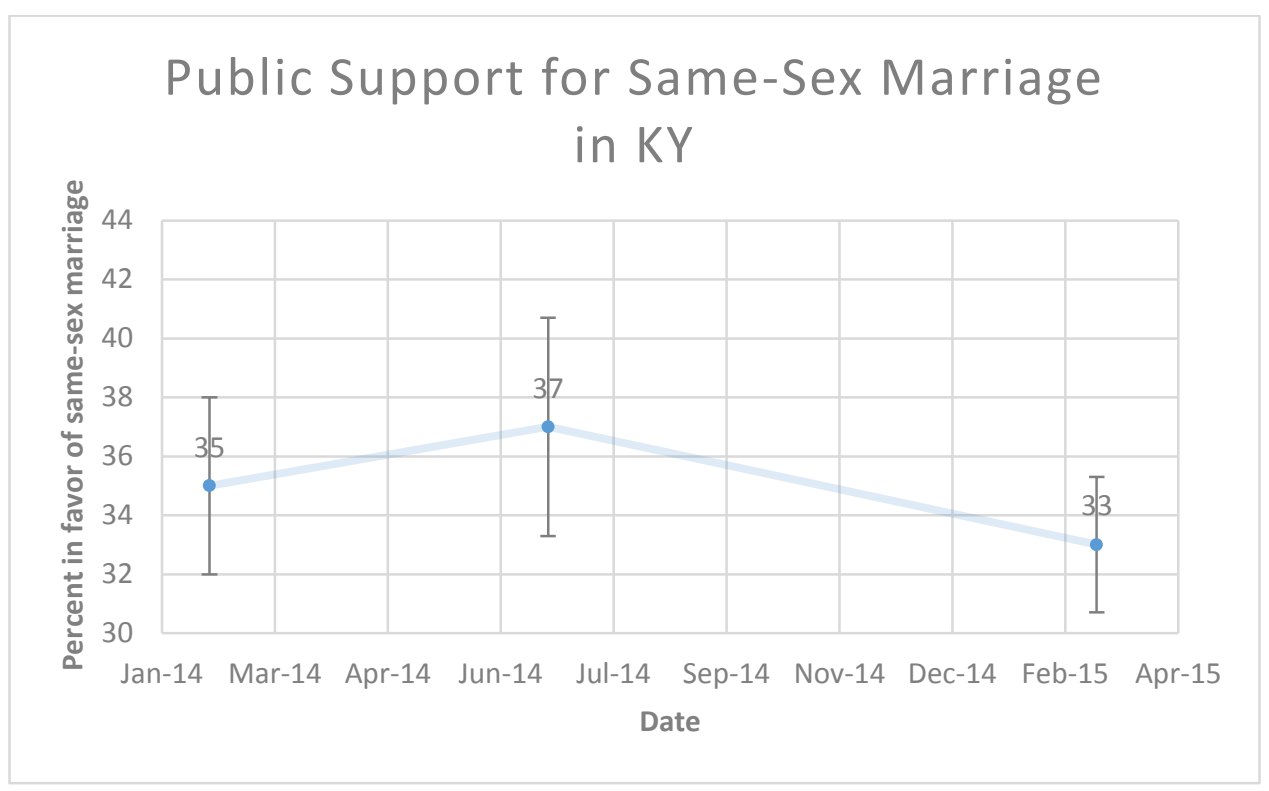

Notes: Data are drawn from the Bluegrass Poll (January 2014 through March 2015). Respondents were asked, "Do you favor or oppose allowing gays and lesbians to marry in Kentucky? 
Figure 8

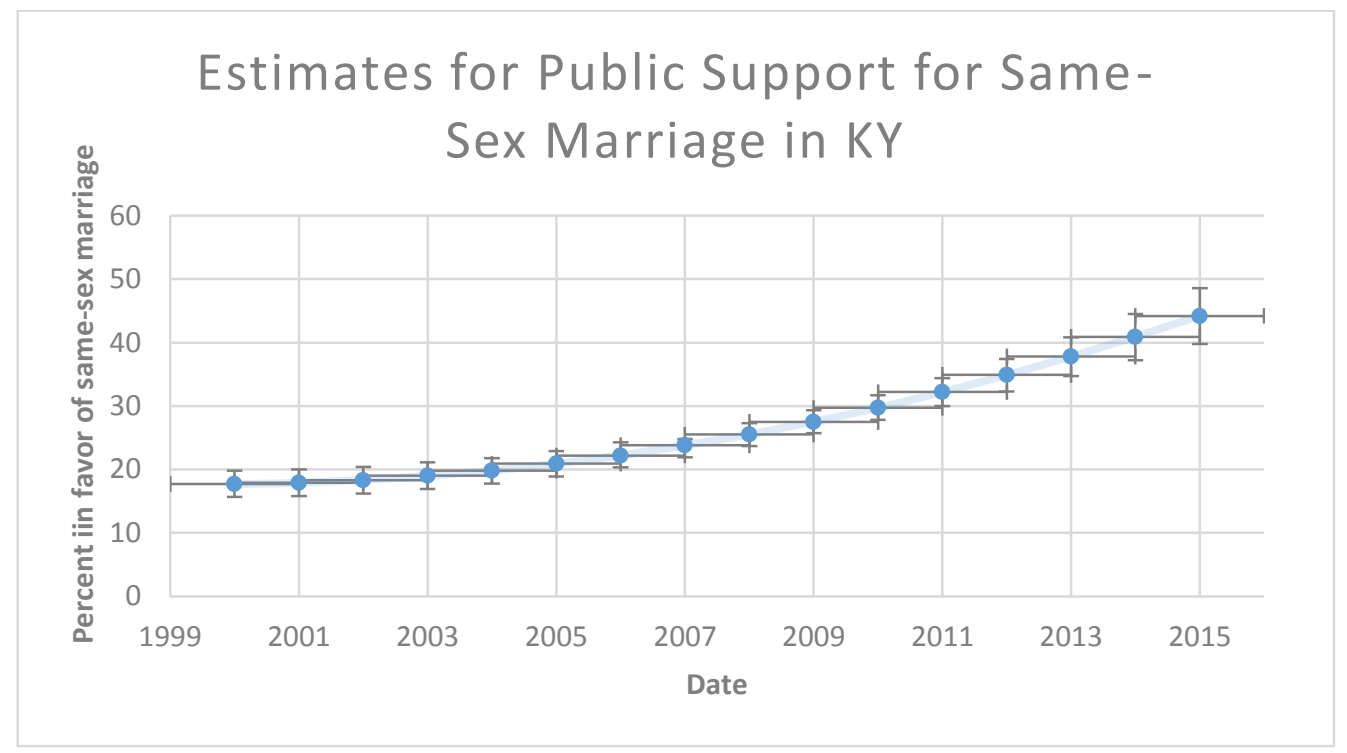

Notes: Data are state estimates from the Williams Institute (2000-2015). 
Figure 9

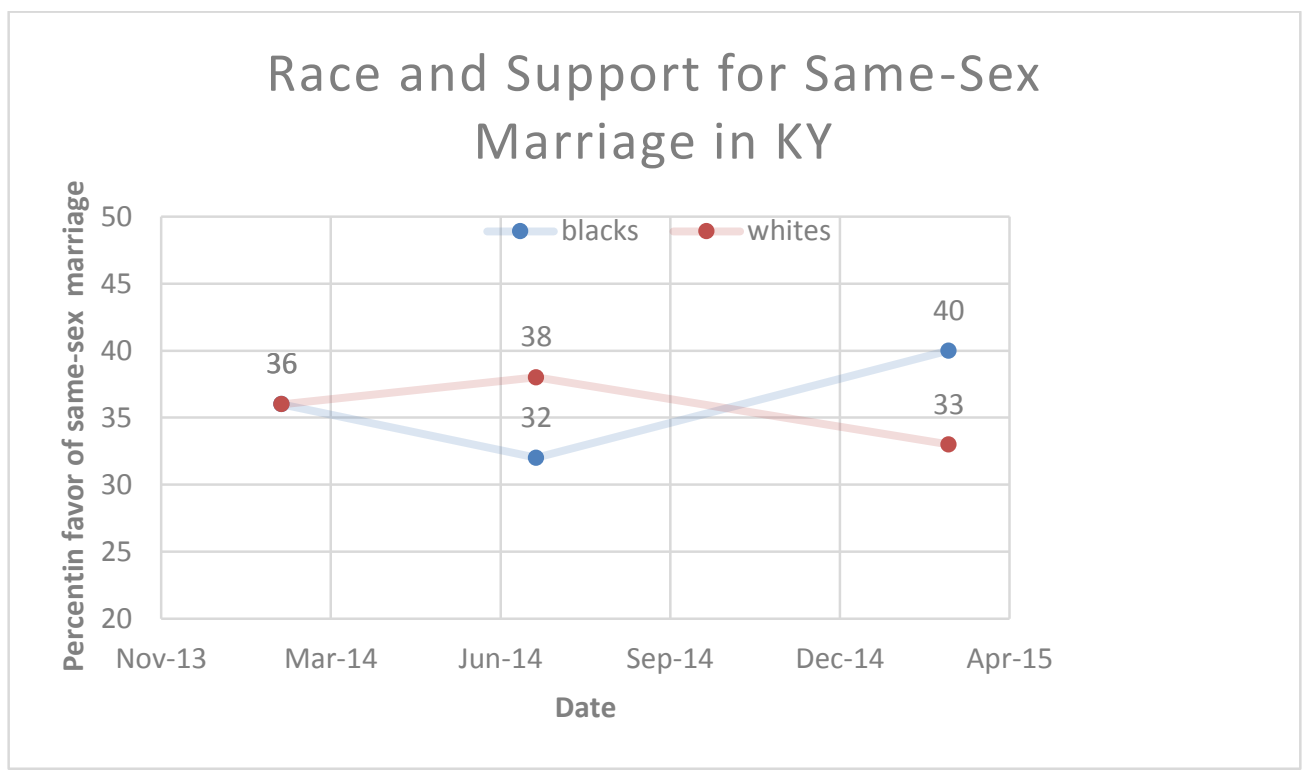

Notes: Data are drawn from the Bluegrass Poll (January 2014 through March 2015).

Respondents were asked, "Do you favor or oppose allowing gays and lesbians to marry in Kentucky? 


\section{Appendix}

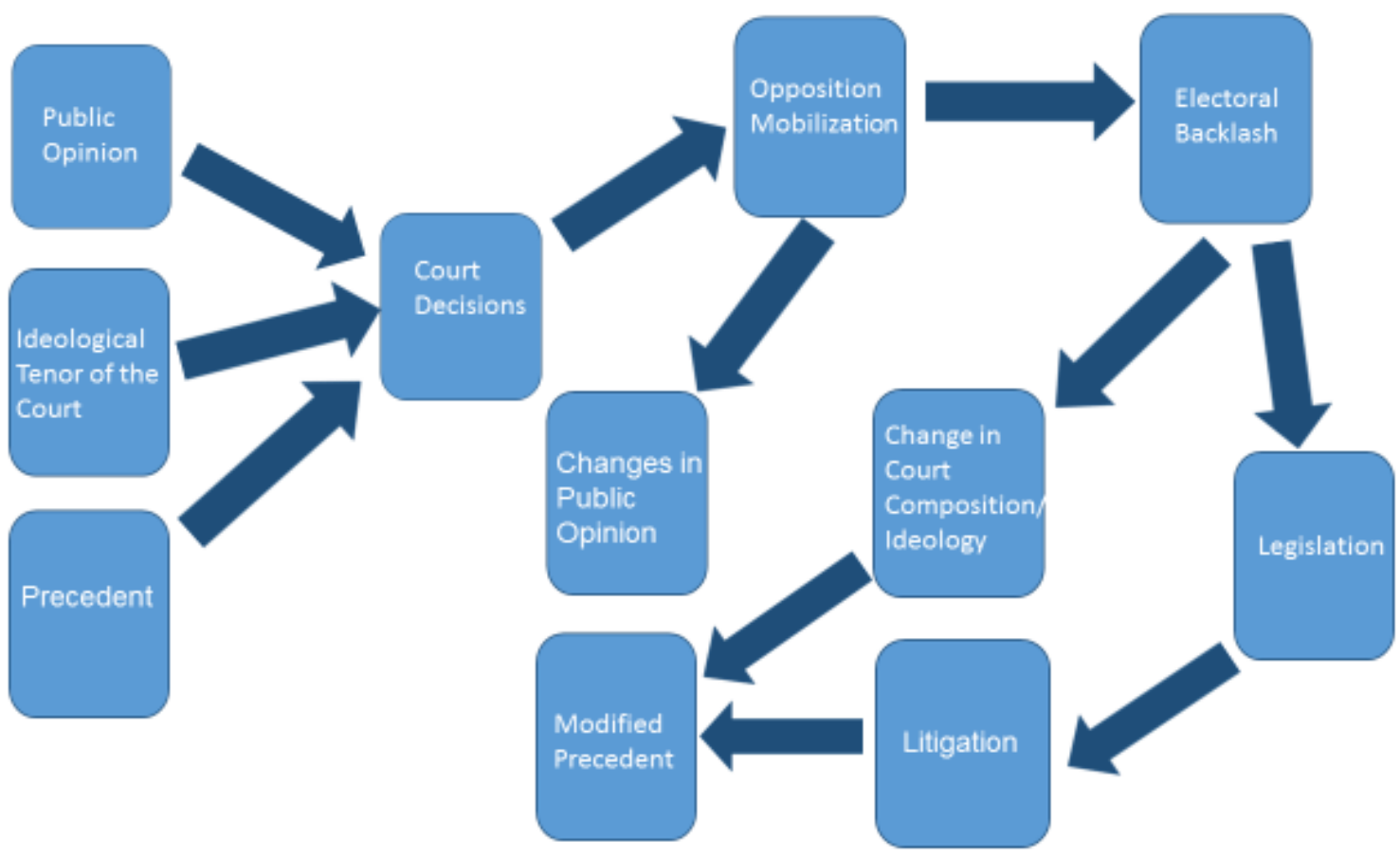

